NBER WORKING PAPER SERIES

\title{
THE EFFECT OF THE ECONOMIC COLLAPSE IN ICELAND ON THE PROBABILITY OF CARDIOVASCULAR EVENTS
}

\author{
Kristín H. Birgisdóttir \\ Arna Hauksdóttir \\ Christopher J. Ruhm \\ Unnur Anna Valdimarsdóttir \\ Tinna Laufey Ásgeirsdóttir \\ Working Paper 25301 \\ http://www.nber.org/papers/w25301
}

\author{
NATIONAL BUREAU OF ECONOMIC RESEARCH \\ 1050 Massachusetts Avenue \\ Cambridge, MA 02138 \\ November 2018
}

We express our gratitude to Statistics Iceland, the Directorate of labor, the Directorate of Health, and Landspitali University Hospital for provision of the data used in this study. Furthermore, the authors would like to thank Jóhanna Gunnlaugsdóttir at The Icelandic Heart Association for being a source of helpful advice. Financial support from the Icelandic Research Fund (IRF grant number 130611-052) and The University of Iceland Eimskip Fund is gratefully acknowledged. The views expressed herein are those of the authors and do not necessarily reflect the views of the National Bureau of Economic Research.

NBER working papers are circulated for discussion and comment purposes. They have not been peerreviewed or been subject to the review by the NBER Board of Directors that accompanies official NBER publications.

(C) 2018 by Kristín H. Birgisdóttir, Arna Hauksdóttir, Christopher J. Ruhm, Unnur Anna Valdimarsdóttir, and Tinna Laufey Ásgeirsdóttir. All rights reserved. Short sections of text, not to exceed two paragraphs, may be quoted without explicit permission provided that full credit, including (C) notice, is given to the source. 
The Effect of the Economic Collapse in Iceland on the Probability of Cardiovascular Events

Kristín H. Birgisdóttir, Arna Hauksdóttir, Christopher J. Ruhm, Unnur Anna Valdimarsdóttir, and Tinna Laufey Ásgeirsdóttir

NBER Working Paper No. 25301

November 2018

JEL No. I1,I10,I15

\section{$\underline{\text { ABSTRACT }}$}

We explore whether the 2008 economic collapse in Iceland and subsequent economic crisis affected the probability of ischemic heart disease (IHD) events, independent of regular cyclical effects attributed to typical economic conditions. We estimate linear probability models using administrative data on IHD events, earnings and balance-sheet status, as well as unemployment for all Icelanders aged 16 and older in 2000-2014.

We find that the sharp change in economic conditions in 2008 had a positive long-term effect on the probability of cardiovascular events in both males and females. In absolute terms these effects were small but often statistically significant and contrast with the finding that general businesscycle fluctuations operated in the opposite direction. Several potential mediators were correlated with the probability of IHD events, but their inclusion had little effect on the estimated economic crisis coefficients. A statistically significant business-cycle effect is found for both genders indicating. Thus the general business cycle and the economic collapse in 2008 and subsequent crisis can be thought of as separate phenomena with differing effects on IHD. This research contributes to the literature by exploiting a unique circumstance affecting a whole population to explore its effects on individuals, using exceptional register data.

Kristín H. Birgisdóttir

Faculty of Economics

University of Iceland

Oddi v/Sturlugötu

101 Reykjavík

Iceland

khb6@hi.is

Arna Hauksdóttir

Faculty of Medicine

Center of Public Health Sciences

University of Iceland

Sturlugötu 8

101 Reykjavík Iceland

Iceland

arnah@hi.is

Christopher J. Ruhm

Frank Batten School of

Leadership and Public Policy

University of Virginia

235 McCormick Rd.

P.O. Box 400893

Charlottesville, VA 22904-4893

and NBER

ruhm@virginia.edu

\author{
Unnur Anna Valdimarsdóttir \\ Faculty of Medicine \\ Center for Public Health Sciences \\ University of Iceland \\ Sturlugötu 8 \\ 101 Reykjavík \\ Iceland \\ unnurav@hi.is \\ Tinna Laufey Ásgeirsdóttir \\ Faculty of Economics \\ University of Iceland \\ Oddi v/Sturlugötu \\ 101 Reykjavík \\ Iceland \\ ta@hi.is
}




\section{The effect of the economic collapse in Iceland on the probability of}

\section{cardiovascular events}

\section{Introduction}

Following booming economic times in the early 2000s, Iceland experienced an economic collapse that was unique in terms of speed, scope, and severity, and can almost be pinpointed to a single date, October $6^{\text {th }} 2008$, when Iceland's Prime Minister announced the risk of national bankruptcy (The Prime Minister's Office, 2008). The impact of the collapse was widely felt; many people's savings vanished with the crash of the Icelandic stock market, monthly unemployment rates tripled and remained high compared to the pre-crisis long-term rate of around 2.5-3\% (Statistics Iceland, n.d.-c), real wages dropped by $13 \%$ from the beginning of 2008 to spring of 2010 (Statistics Iceland, n.d.-h), and the average Icelandic homeowner experienced an approximately $27 \%$ decline in the real equity of their home between 2007 and 2010 (Statistics Iceland, n.d.-i). Even those not directly experiencing a dramatic change in their own lives felt the shock through media and personal relationships. The crisis following the collapse was relatively short lived and the Icelandic economy experienced substantial recovery as early as 2011 , with decreasing unemployment (Statistics Iceland, n.d.-h); growing GDP (Statistics Iceland, n.d.-f); stabilizing of prices with relatively low inflation (Statistics Iceland, n.d.-b); climbing housing prices, and increased equity (Statistics Iceland, n.d.-j). It is thus clear that dramatic changes, from boom-to-bust and subsequent recovery, took place within a short period of time.

Economic fluctuations are not all the same, and the collapse in Iceland can be characterized as a particularly severe shock.

Whether the health effects of such a shock can be fully attributed to general business-cycle effects is not well understood. In this study, we examine whether the Icelandic economic collapse affected cardiovascular health, independent of regular cyclical effects that can be attributed to more typical economic fluctuations. Using register-based individual data on earnings, unemployment, and cardiovascular diseases for the Icelandic population we exploit this unique occurrence to examine the relationship between the economic collapse and cardiovascular health, specifically focusing on ischemic heart disease (IHD) (also known as coronary heart disease), the leading cause of death worldwide (World Health Organization, 2014). 
Although dating further back, the literature on business cycles and health received renewed impetus when Ruhm (2000) found that mortality increases in good economic times. Other studies followed, using different data, methods, and health outcomes most with results consistent with those of Ruhm's (Ariizumi \& Schirle, 2012; Gerdtham \& Ruhm, 2006; Tapia Granados, 2005; Tapia Granados \& Ionides, 2017; van den Berg et al., 2017), but others with conflicting findings of a counter-cyclical relationship (Economou et al., 2008; Gerdtham \& Johannesson, 2005; Svensson, 2007, 2010). There is furthermore evidence that the procyclicality of mortality has fallen, at least in the United States, in recent years (Ruhm, 2015). Although limited, some recent evidence raises the possibility that large economic shocks have effects that differ in relative size or direction from those of smaller shocks (Ruhm, 2016). The reason for such differences is not clear, but context appears to matter, and a fuller picture is slowly emerging with each additional study showing results from different types of cycles, outcomes, and institutional or social settings.

In recent years the literature has moved towards more detailed analyses exploring the possible pathways of estimated effects. Those include changes in personal income, health behaviors, and individual labor-market status (Asgeirsdottir et al., 2016a; Asgeirsdottir et al., 2014a; Asgeirsdottir et al., 2016b; Asgeirsdottir et al., 2014b; Birgisdottir et al., 2017; Jonsdottir \& Asgeirsdottir, 2014; Miller et al., 2009; Olafsdottir \& Asgeirsdottir, 2015; Olafsdottir et al., 2014; Ruhm, 2000, 2003, 2007, 2015). Miller et al. (2009) found that the added deaths related to a drop in the unemployment rate are concentrated among age groups that are mostly out of the labor force, indicating that work-related stress or substitution between work and health production are not primarily to blame. Ruhm (2000) showed that changes in personal income play a negligible part in in the relationship between business cycles and health, but he has also pointed to risky behaviors (such as smoking and drinking) as potential pathways (Ruhm, 2003, 2004, 2015). Conversely, increased income could have protective effects by raising the consumption of health care and other health-improving activities, especially in countries where a substantial portion of health services are privately funded (Gerdtham \& Ruhm, 2006).

The Icelandic economic collapse has provided researchers with useful identifying variation of the effects of the collapse given the sharp contrast in economic performance before versus after October 2008. The health outcomes previously explored include a number of determinants of cardiovascular diseases (CVD) (Asgeirsdottir et al. (2016a); Asgeirsdottir et al. (2014a); Asgeirsdottir et al. (2016b); Asgeirsdottir et al. (2014b); Birgisdottir et al. (2017); (Eiriksdottir et al., 2015); Hauksdottir et al. (2013); Jonsdottir and Asgeirsdottir (2014); McClure et al. (2012); Olafsdottir and Asgeirsdottir (2015); Olafsdottir et al. (2014)). Using survey data from 2007 and 2009, Asgeirsdottir et al. (2014b) find a short-term increased risk of male hypertension following the economic collapse and with an added wave of the same data for 2012, Birgisdottir et al. (2017) also show a longer-run rise in hypertension among 
females, and Eiriksdottir et al. (2015) find an increased risk of gestational hypertension after the economic collapse. Furthermore, data from the emergency departments in Iceland's capital area indicate a considerable increase in cardiac emergency department attendance during the first week of the economic collapse, particularly among females, and particularly with IHD diagnoses (Gudjonsdottir et al., 2012). This negative effect on heart health is not in accordance with results from other business cycles over the years in Iceland, that have generally shown null-effects (Birgisdóttir \& Ásgeirsdóttir, 2017) or negative effects on heart health during times of increased economic activity (Ólafsdóttir et al., 2016). As our analysis includes both general business-cycle fluctuations as well as the sharp collapse associated with the Great Recession, we aim to separate the two and estimate their relationship to cardiovascular health. Specifically, we assess whether the effect of the economic collapse of 2008 was in keeping with the general business-cycle effect or not. This is accomplished by using more comprehensive and detailed data than what has been carried out in the studies previously mentioned, but those only use aggregate data or small samples. In this study we use individual-level data from registers on the full adult population in Iceland, in the hope that the scope of the study can tie together results found in the previous literature.

Stress is known to raise the risk of IHD, as do various environmental factors (American Heart Association, 2015; Arbab-Zadeh et al., 2012). The medical literature distinguishes between long-term risk factors such as age, hypertension, and cholesterol levels (Muller et al., 1994) versus acute stressors such as natural disasters that come without warning (Dimsdale, 2008). Recent literature has also shown that acute stressors, such as earthquakes can have long-term effects on cardiovascular-disease risk factors (Li et al., 2017). Cardiac events increase in the immediate aftermath of such acute life stressors (Leor et al., 1996), and research shows that transitory factors affect cardiovascular mortality. For example, peaks have been found in the morning hours (Cohen et al., 1997), and on Mondays (Arntz et al., 2001). Long-term stressors associated with increased risk of coronary events include chronic work stress (Matthews \& Gump, 2002) and marital stress (Orth-Gomér et al., 2000). Furthermore, changes in the rate of coronary events might emerge as immediate responses to circumstances (Ruhm, 2007) or as a delayed consequences of accumulated effects (American Heart Association, 2015; Olafsdottir et al., 2016). Stress, particularly among females, rose as a result of Iceland's economic crash (Hauksdottir et al., 2013). Therefore, a study on the effects of a stressful event such as an economic collapse on coronary diseases is of high relevance.

This study contributes to the related literature by examining the short-term effects of the Icelandic economic collapse on the probability of IHD events (in the first months following the unofficial date of economic collapse, on October $6^{\text {th }} 2008$ ), as well as the longer-term impacts over the subsequent two years. Our extensive microdata also permits a preliminary exploration of the 
pathways through which both the initial shock effect as well as the longer-term effects of the crisis operate. Specifically, we examine mechanisms related to changes in individual personal income, equity, and own unemployment, and we also consider the role of general business cycles, as measured by aggregate unemployment, one important external factor related to a deteriorating economy.

\section{Data}

The data used originate from five registers that were merged using personal identifiers. These include tax, unemployment and cause of death registers, as well as registers of all incidences of coronary events at Reykjavík hospitals and of acute coronary events at the emergency ward at Landspitali University Hospital over the years 2000-2014. Data on the monthly aggregate unemployment rate was obtained from the Directorate of labor (Directorate of labour, n.d.).

Merging of the data was contingent on permissions from the Data Protection Authority (2015101288pS) and the National Bioethics Committee (13-050) in Iceland and was performed using encrypted personal identifiers. Our sample is characterized both as a population sample and a flow sample with observations over a fixed time. Specifically, a population sample of all Icelanders living in Iceland and aged 16 and older in 2000 is used, supplemented by a flow sample of later entrants consisting of persons reaching the age of 16 during the study period. The result is a follow up of multiple birth cohorts ending at a single time point (the end of the calendar year 2014), with information provided on each individual for up to 15 years. Sample exits occur only because of death during the study period or missing data for follow-up, such as due to emigration. A simple comparison of characteristics of those with and without missing data suggests that the latter group are younger, have fewer children, and lower income, and are less likely to have experienced an admission to hospital due to IHDs. This is expected, reflecting the greater mobility of younger and healthier people. The individual characteristics of those with missing data do not change during the crisis years, reducing concern about systematic attrition in those years. A priori we would not expect results to be affected by attrition in the short-term analysis, but in the long run this could be of greater concern. The use of the full population of individuals of qualifying age, rather than a sample, means that we do not worry about selection bias. However, our knowledge is limited to the information contained in the registers. For instance, we lack data on income, employment, or health prior to 2000, and therefore cannot fully account for those factors. The final sample includes 188,354 males and 171,964 females, 87,469 and 89,785 of whom were observed during the whole study period (180 months). The average follow-up time is 130 months for females and 120 months for males, yielding an 
unbalanced panel of $45,035,064$ person-month observations. A total of 30,997 IHD events are encountered in the sample (20,081 for males and 10,916 for females).

\subsection{Data registers}

Information on personal income and equity, as well as demographic information on gender, age, marital status, number of children, and residency was obtained from the tax register. The data accurately capture income changes, which reflect variation in employment, hours worked or wages. To reduce traceability in the data, Statistics Iceland top-coded the number of children to 3. This was done to 33,743 observations. Individuals turning 100 years old during the study period were re-coded by Statistics Iceland so that their age was 95 in the first year they entered the dataset, with one year added to age annually thereafter. This was done for 820 observations (332 individuals). Personal income and equity were converted to 2014-year krona.

Unemployment information came from the unemployment register, provided by the Directorate of labor, covering the period February 2000 to December 2014, during which 91,963 individuals (47,731 males and 44,232 females) are listed in the unemployment register. The unemployment register does not contain information on those who lost their jobs and did not register at the Directorate of labor, e.g. because they were immediately rehired or decided to further their education.

From the cause of death register we use data on all incidences of deaths due to diseases of the circulatory system (ICD 10 codes I00-199), where IHDs (ICD 10 codes I20-I25) were listed as an underlying or contributing cause of death. In our sample, this amounts to 6,813 individuals for the whole study period for IHDs (3,980 for males and 2,833 for females).

From the emergency ward admission register, we use data on all admissions to the emergency wards at Reykjavík's hospitals where patients have a diagnosis of IHD. Some of these are also found in the hospital admission register, as patients may be admitted to another ward after discharge from the emergency ward. In such cases we treat both admissions as one event (to avoid double counting) with the date of admission taken as the date entering the emergency department. Similarly, the original admission date is used for cases leading to death.

The hospital and emergency ward admission registers contain information on all admissions where patients' diagnosis contain the ICD 10 codes I20-I25 (IHDs), but do not contain information on the patients' medical history. As a result, we cannot control for prior instances (before the year 2000) of IHD events, nor can we restrict our analysis to first-time events. 


\subsection{Descriptive Patterns}

We define an IHD event as either death, hospital or emergency ward admission due to IHDs. Figure 1 shows yearly numbers of IHD events from our data. In Iceland, as in most countries around the world, a downward trend has been evident in the cardiovascular mortality rate in recent decades. Our data, which includes morbidity and mortality figures, reveals a downward trend in IHD events, consistent with the global trend in mortality (the figure provides raw numbers rather than mortality or incidence rates).

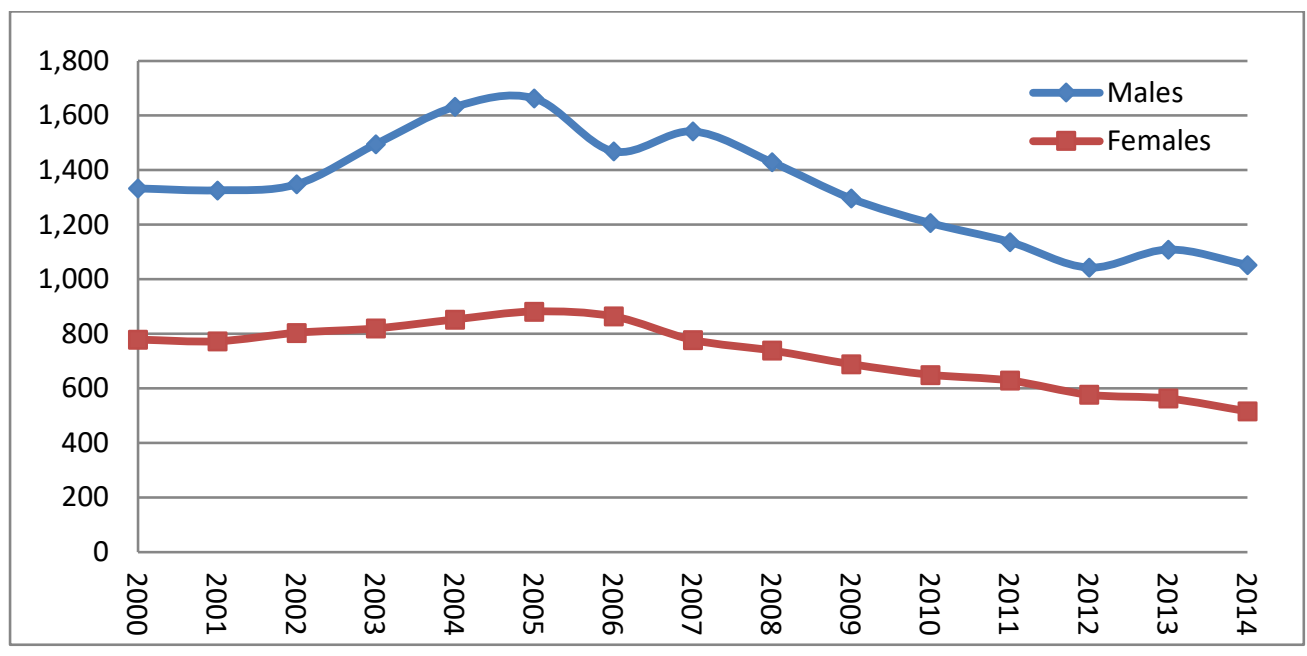

Figure 1: Number of IHD events per year. An event is categorized as either death, hospital or emergency ward admission.

\subsection{Data limitations}

Inpatient cases were all obtained from hospitals in the Reykjavík area. This was considered an adequate proxy for coronary events for the whole population, as the majority of Icelanders (around two thirds of the population) live in Reykjavík and the surrounding area. Additionally, many patients living elsewhere are treated in Reykjavík because smaller hospitals have limited resources such as the availability of heart specialists. Evidence for this was obtained from a preliminary investigation showing that the residence of those suffering IHDs was distributed throughout the country. Furthermore, no other hospitals outside the Reykjavík area have a cardiovascular ward or perform cardiovascular surgeries.

\section{Methodology}

Using a linear probability model, we explore the probability of IHD events as a function of covariates, including calendar time and age; October $6^{\text {th }} 2008$ is the reference date for the economic collapse. A linear time trend and seasonality are included to capture 
period specific effects on the risk of an IHD, such as variations in treatments and diagnosis, as well as trends in lifestyle factors that might reasonably be linked with cardiovascular health, like exercise and smoking. Age dummy variables, representing each twoyear age cohort, are included to capture combined cohort effects and those of individual age-related risk factors. Individual fixed effects are also included to control for time-invariant factors that are spuriously correlated with economic conditions across individuals.

The identification assumption is that after including controls, the probability of an IHD event would have been the same before and after October $6^{\text {th }} 2008$, had the economic collapse not occurred.

The outcome variable is a binary indicator for the IHD event, taking the value one for each period of event occurrence and zero otherwise. From the hospital admission register we use data on all admissions where patients have a diagnosis of IHD (ICD 10 codes 120-125). From the cause-of-death register we use data where a listed cause of death is IHD (underlying or contributory).

In model 1, which is a conventional business-cycle model, the covariates include factor variables for marital status (single, married, cohabitating, or widowed) and residency (i.e. whether an individual resides in the capital region of Iceland, or in seven other regions) and a continuous variable for number of children. The explanatory variable of primary interest in model 1 is the aggregate unemployment rate, which provides information on the degree to which the overall economic environment influences an individual's heart health and, for the purposes of this study, is used to distinguish between the effects of typical business-cycle fluctuations versus those of an economic collapse. Following the literature on business cycles and health, we use the monthly aggregate unemployment rate to proxy the macro economy (see for example Eliason and Storrie (2009); Gerdtham and Johannesson (2003); Miller et al. (2009); Ruhm (2000, 2003, 2005, 2007)).

In model 2 we explore the immediate effect of the economic collapse of 2008 on the probability of an IHD event by using a binary indicator for the 3-month period of October, November, and December of 2008, instead of the aggregate economic indicator; the associated coefficient indicates whether there is a shift in the probability of an IHD event away from the time trend during October 2008 - December 2008. Although October $6^{\text {th }}$ can be designated to be the start of the economic crash, our data does not allow such detailed timing for the analysis. However, since the $6^{\text {th }}$ of October falls very early in the month, we feel that calendar months provide sufficient detail for us to draw meaningful conclusions from, despite misclassification of the first 5 days of October into a treatment group. Since the incidence of IHDs is relatively low, we do not expect these short-term effects to be measured with 
great precision but include them because of prior literature indicating effects of transitory changes in a variety of factors on the risk of an IHD event.

In model 3, we perform a long-term analysis because IHDs are often the result of a gradual process triggered by stressful events. To do so we replace the time dummy variable capturing the short-term crisis effect (October-December 2008) with two twelvemonth dummy variables for the periods October 2008 - September 2009 and October 2009 - September 2010.

In model 4 we append the binary indicator for October-December of 2008 to the basic business-cycle model (model 1), and in model 5 we similarly add the binary indicators for October 2008 - September 2009 and October 2009 - September 2010 to the basic business-cycle model. The purpose of including both the collapse/crisis dummies and the business-cycle indicators in the same model is to assess if or to what degree, any found effects from the collapse/crisis (models 2 and 3 ) can be attributed to traditional business-cycle effects and to what extent they are separate effects. Similarly, comparisons to model 1 can indicate whether possible business-cycle effects are strengthened by this exceptionally strong single-time fluctuation within the data or not.

We also estimate models that include additional controls for potential individual mediators including total income, real equity, and individuals' own unemployment to all models. For the sake of brevity, full results from the mediation analysis are not shown in the main results (tables 1 and 2) but can be found in the appendix (tables A1-A14). However, the coefficients on the macroeconomic variables of key interest, with all mediators collectively included, are shown in tables 1 and 2 and labelled models $4 \mathrm{~b}$ and $5 \mathrm{~b}$.

\subsection{Subgroup analysis}

In addition to the full sample estimates, we separately run models for the working-age population, defined here as $21-70$ year olds, on one hand and those above 70 on the other hand. The lower age limit for the working-age population is justified by the fact that although schooling is mandatory only up to 16 years old, a vast majority of Icelanders finish upper secondary school, which typically ends at age 20: over 90 percent of the 16-year old Icelandic population was enrolled in school during the study period, and over 50 percent of the 20-year old population was enrolled in school at either the upper secondary or tertiary level (Statistics Iceland, n.d.-d, e). The effective retirement age in Iceland for the study period is around 70 years old, (OECD, 2016) and is therefore used as the upper bound for the working-age population. A separate analysis is performed for those over 70 years old, since most IHD events occur among that age group, and we might expect different results than for those in the working-age sample, especially when examining individual-level mechanisms. For example, a person's own unemployment is an important 
mechanism through which effects of the business cycle or collapse run, but such effects are hardly of importance in those above 70, whereas factors such as income and equity could be of importance. Since a wide literature covers the differences in the incidence of CVDs in males and females, we also stratify all estimates by gender.

We furthermore estimate models where acute myocardial infarction (AMI), otherwise known as heart attack, is the dependent variable. AMI is a subcategory of IHD (ICD 10 code I21-I22) and can be acutely life threatening. With a stressful event such as an economic collapse we might expect the probability of AMIs in particular to be affected, especially among the medically vulnerable. However, as the number of AMI events in the sample is small (a total of 10,$875 ; 7,172$ for males and 3,703 for females) we do not expect to measure the effects of the economic collapse and crisis on the probability of AMI events with great precision. Therefore, those are not our primary focus and should be interpreted cautiously, although reported in the appendix for completeness (tables A1-A4 for males and A8-A11 for females).

All regressions were performed with STATA 14.1 statistical software. We report robust standard errors clustered on individuals.

\section{Results}

Results are reported here separately for males (table 1) and females (table 2). They include estimations with variables describing economic conditions one at a time, but also include business-cycle and collapse/crisis effects at the same time to estimate the

relationship between those. Tables containing full results with models using individual-level mediators are shown in the appendix. When examining models with mediators it should be kept in mind that the purpose of their inclusion is not to focus on those coefficients themselves, as they need not show unbiased estimates of causal effects due to endogeneity. The purpose is rather to see how the main coefficients of interest are affected by their inclusion. The main variation that we claim is exogenous is the macroeconomic climate and the collapse of 2008. Tables 1 and 2 show the coefficients of greatest interest in this study from models 1-5b (numbered in the tables and laid out in the methods section) and are divided into three panels displaying results for the full, working-age, and over-70-years-old samples.

\subsection{Males}

For the full sample (table 1, top panel), a negative and statistically significant relationship is consistently found between aggregate unemployment (indicating general business cycles) and IHD, indicating that harder economic times are beneficial for heart health. However, a positive relationship is found between the collapse (short-run effect) and crisis (long-run effect) on one hand and 
probability of IHD on the other hand, indicating that the collapse of 2008 and the following recession were compromising for heart health. The short-run coefficient, although positive in all models, is only barely statistically significant in model 2 , and falls just short of being statistically significant in other models. Comparison across models indicates that the collapse effect (short-run) and the business-cycle effect are largely independent of each other as indicated by minimal changes in coefficients for both when estimated separately or simultaneously. However, the business-cycle and the crisis (long-run) coefficients change substantially between models in which they are estimated separately and simultaneously. In fact, the coefficients more than double in size when estimated simultaneously, emphasizing the difference between types of economically difficult circumstances. Addition of our three individual-level mediators (models $4 b$ and $5 b$ ) does not substantially change results (compared to models 4 and 5 ). Models adding one mediator at a time can be seen in the appendix (table A5), and tell a similar story of minimal mediating effects from individual-level factors.

When estimating the models for the working-age population and those over 70 years of age separately, some statistical power is lost, compared to the full sample. Results from the full sample and the working-aged males in model 5 show smaller long-term crisis coefficients (and general business-cycle effects), whereas the coefficients are generally larger in absolute value than for full or working-aged sample. Although the stratification leads to statistical significance that is generally lower than in the full sample, with most coefficients not statistically significant, the size of the point estimates indicates that those over 70 years of age are to a large extent driving the results found in the full sample. Although point estimates and statistical significance are different in the subsamples, compared to the full sample results, the general pattern of results between the estimation models is similar.

It should be kept in mind that found effects are small. For example, when exploring the business-cycle model with long-term crisis coefficients together for the full sample (model 5, top panel), the results reveal that in the first twelve months the probability of being hospitalized or dying from IHD is 0.0122 percentage points higher than in the average twelve-month period in the sample, and for the latter twelve months the probability is 0.0098 percentage points higher. The average yearly number of IHD events for men in the dataset is 1,339 IHD and hence the magnitude of the found effects is rather small, amounting to approximately $13-16$ extra cases in each of the two years following the collapse. Results for AMI as an outcome variable (see tables A1-A4 in the appendix) generally show coefficients that are of the same sign but smaller in magnitude than those for IHD, and with lower statistical significance. 


\subsection{Females}

In general, the results for women tell a similar story to those of men, but with coefficients that are smaller in absolute terms and generally of lower statistical significance as can be expected do to fewer events in women. Business-cycle estimates consistently show that harsh economic times are beneficial for heart health, although only statistically significant once the suppressing effect of the crisis (long-run effect) is also included in the model. In the full sample (table 2, top panel), a positive long-term relationship is found for both the first twelve and twenty-four months (only statistically significant in the latter twelve-month period in model 3), that increases substantially in absolute value and statistical significance when estimated simultaneously with the business-cycle effect. The larger coefficients found for the latter twelve-month period than the first twelve months in the long-term analyses are conceivably explained by a lagged response to accumulating effects (American Heart Association, 2015). No statistically significant collapse effect (short-term) was found for women although a small negative point estimate that doesn't change across models is consistent with what was found for men.

When comparing the full, working-aged, and over-70-year-old samples the results suggest that the effects found for the full sample are driven mostly by the elderly. The general business cycle seems to affect them to a greater extent than younger females, and similarly are the coefficients for the long-run crisis larger, although not always precisely measured. Although some of the mediators studied were independently related to the probability of IHD, the main estimated economic-crisis effect was insensitive to their inclusion (full results for the mediation analysis for females are shown in the appendix, tables A13 -A14).

Again we emphasize the size of the effects when exploring model 5, with business-cycles and the long-term crisis coefficients simultaneously estimated. The results reveal that in the first twelve months the probability of an IHD event is 0.0052 percentage points higher than in the average twelve-month period in the sample, and for the latter twelve months the probability is 0.0080 percentage points higher. The average yearly number of IHD events is 728 IHD for women in the dataset. Therefore, the magnitude of the found effects is very small, only amounting to circa 3-5 extra cases in each of the two years following the economic collapse. The results for AMI as an outcome similarly show a long-term crisis effect for women, but the coefficient for the business-cycle indicator is generally the opposite of what we find when studying IHD (see tables A8-A11 in the appendix). As stated earlier those results should be interpreted cautiously due to the small number of AMI events in the sample. 
Table 1: Estimates of the probability of an IHD event among men

\begin{tabular}{|c|c|c|c|c|c|c|c|}
\hline Full sample & $(1)$ & $(2)$ & (3) & (4) & $(4 b)$ & (5) & $(5 b)$ \\
\hline \multirow{2}{*}{ Unemployment rate } & $-0.0903^{* * *}$ & & & $-0.0893^{* * *}$ & $-0.1007^{* * *}$ & $-0.2041^{* * *}$ & $-0.2173^{* * *}$ \\
\hline & $(0.0322)$ & & & $(0.0322)$ & $(0.0326)$ & $(0.0421)$ & $(0.0423)$ \\
\hline \multirow{2}{*}{ Oct 2008 - Dec 2008} & & $0.0082^{*}$ & & 0.0080 & 0.0081 & & \\
\hline & & $(0.0050)$ & & $(0.0050)$ & $(0.0050)$ & & \\
\hline \multirow{2}{*}{ Oct 2008 - Sep 2009} & & & $0.0050^{*}$ & & & $0.0122^{* * *}$ & $0.0124^{* * *}$ \\
\hline & & & $(0.0026)$ & & & $(0.0030)$ & $(0.0030)$ \\
\hline \multirow{2}{*}{ Oct 2009 - Sep 2010} & & & 0.0098 & & & $0.0098^{* * *}$ & $0.0099^{* * *}$ \\
\hline & & & $(0.0025)$ & & & $(0.0030)$ & $(0.0030)$ \\
\hline \multicolumn{8}{|l|}{ Working-age sample } \\
\hline \multirow{2}{*}{ Unemployment rate } & $-0.0639^{* *}$ & & & $-0.0631^{* *}$ & $-0.0663^{* *}$ & $-0.1521^{* * *}$ & $-0.1546^{* * *}$ \\
\hline & $(0.0277)$ & & & $(0.0277)$ & $(0.0280)$ & $(0.0357)$ & (0.0359) \\
\hline \multirow{2}{*}{ Oct 2008 - Dec 2008} & & 0.0069 & & 0.0067 & 0.0067 & & \\
\hline & & $(0.0043)$ & & $(0.0043)$ & $(0.0043)$ & & \\
\hline \multirow{2}{*}{ Oct 2008 - Sep 2009} & & & $0.0042^{*}$ & & & $0.0095^{* * *}$ & $0.0094^{* * *}$ \\
\hline & & & $(0.0022)$ & & & $(0.0026)$ & $(0.0026)$ \\
\hline \multirow{2}{*}{ Oct 2009 - Sep 2010} & & & 0.0011 & & & $0.0076^{* * *}$ & $0.0075^{* * *}$ \\
\hline & & & $(0.0022)$ & & & $(0.0026)$ & $(0.0026)$ \\
\hline \multicolumn{8}{|c|}{ Over 70 years old sample } \\
\hline \multirow{2}{*}{ Unemployment rate } & -0.3696 & & & -0.3686 & -0.3947 & $-0.6405^{*}$ & $-0.6972^{* *}$ \\
\hline & $(0.2482)$ & & & $(0.2483)$ & $(0.2483)$ & $(0.3351)$ & $(0.3355)$ \\
\hline \multirow{2}{*}{ Oct 2008 - Dec 2008} & & 0.0079 & & 0.0062 & 0.0084 & & \\
\hline & & $(0.0400)$ & & $(0.0400)$ & $(0.0400)$ & & \\
\hline \multirow{2}{*}{ Oct 2008 - Sep 2009} & & & 0.0053 & & & 0.0286 & 0.0323 \\
\hline & & & $(0.0205)$ & & & $(0.0245)$ & $(0.0245)$ \\
\hline \multirow{2}{*}{ Oct 2009 - Sep 2010} & & & -0.0040 & & & 0.0238 & 0.0258 \\
\hline & & & $(0.0193)$ & & & $(0.0236)$ & $(0.0236)$ \\
\hline Mediators Included & No & No & No & No & Yes & No & Yes \\
\hline
\end{tabular}

Notes: Point estimates are computed using linear probability model with individual fixed effects, adjusting for age fixed effects, time trend, seasonality, marital status, number of children in the household, and residency. Estimation models 1-5b are indicated by the column numbers (1) - (5b) at the top of the table. Model 1 is a business-cycle model, model 2 a collapse model, and model 3 a crisis model. Model 4 includes business cycles as well as the collapse, and model 5 includes business cycles as well as the crisis period. Models $4 b$ and $5 b$ furthermore include three individual-level mediators: individuals' unemployment, real monthly income, and real equity. Robust standard errors in parentheses. ${ }^{*} p<0.1,{ }^{*} p<0.05,{ }^{* * *} p<0.01$. For the full sample $N=22,570,569$, for the working-aged sample $N=18,349,379$, for the over 70 -year-old sample $N=2,104,560$. Average number of IHD events per year is 1,339 for males. Coefficients are interpreted as changes (in percentage points) in the probability of an IHD event. 
Table 2: Estimates of the probability of an IHD event among women

\begin{tabular}{|c|c|c|c|c|c|c|c|}
\hline Full sample & (1) & (2) & (3) & (4) & (4b) & $(5)$ & (5b) \\
\hline Unemployment rate & $\begin{array}{l}-0.0340 \\
(0.0240)\end{array}$ & & & $\begin{array}{l}-0.0338 \\
(0.0240)\end{array}$ & $\begin{array}{l}-0.0376 \\
(0.0241)\end{array}$ & $\begin{array}{l}-0.1045^{* * *} \\
(0.0303)\end{array}$ & $\begin{array}{l}-0.1100^{* * *} \\
(0.0304)\end{array}$ \\
\hline Oct 2008 - Dec 2008 & & $\begin{array}{l}0.0015 \\
(0.0037)\end{array}$ & & $\begin{array}{l}0.0014 \\
(0.0037)\end{array}$ & $\begin{array}{l}0.0015 \\
(0.0037)\end{array}$ & & \\
\hline Oct 2008 - Sep 2009 & & & $\begin{array}{l}0.0015 \\
(0.0019) \\
0.0035^{*} \\
(0.0019)\end{array}$ & & & $\begin{array}{l}0.0052^{* *} \\
(0.0021) \\
0.0080^{* * *} \\
(0.0023)\end{array}$ & $\begin{array}{l}0.0054^{* *} \\
(0.0021) \\
0.0081^{* * *} \\
(0.0023)\end{array}$ \\
\hline \multicolumn{8}{|l|}{ Working-age sample } \\
\hline Unemployment rate & $\begin{array}{l}-0.0165 \\
(0.0155)\end{array}$ & & & $\begin{array}{l}-0.0147 \\
(0.0156)\end{array}$ & $\begin{array}{l}-0.0152 \\
(0.0156)\end{array}$ & $\begin{array}{l}-0.0232 \\
(0.0198)\end{array}$ & $\begin{array}{l}-0.0220 \\
(0.0199)\end{array}$ \\
\hline Oct 2008 - Dec 2008 & & $\begin{array}{l}0.0010 \\
(0.0024)\end{array}$ & & $\begin{array}{l}0.0009 \\
(0.0024)\end{array}$ & $\begin{array}{l}0.0009 \\
(0.0024)\end{array}$ & & \\
\hline Oct 2008 - Sep 2009 & & & $\begin{array}{l}0.0005 \\
(0.0012)\end{array}$ & & & $\begin{array}{l}0.0013 \\
(0.0014)\end{array}$ & $\begin{array}{l}0.0013 \\
(0.0014)\end{array}$ \\
\hline Oct 2009 - Sep 2010 & & & $\begin{array}{l}-0.0009 \\
(0.0012)\end{array}$ & & & $\begin{array}{l}0.0001 \\
(0.0014)\end{array}$ & $\begin{array}{l}0.0001 \\
(0.0014)\end{array}$ \\
\hline \multicolumn{8}{|c|}{ Over 70 years old sample } \\
\hline Unemployment rate & $\begin{array}{l}-0.0565 \\
(0.1730)\end{array}$ & & & $\begin{array}{l}-0.0584 \\
(0.1732)\end{array}$ & $\begin{array}{l}-0.0466 \\
(0.1735)\end{array}$ & $\begin{array}{l}-0.4802^{* *} \\
(0.2211)\end{array}$ & $\begin{array}{l}-0.4594^{* *} \\
(0.2222)\end{array}$ \\
\hline Oct 2008 - Dec 2008 & & $\begin{array}{l}-0.0115 \\
(0.0265)\end{array}$ & & $\begin{array}{l}-0.0120 \\
(0.0265)\end{array}$ & $\begin{array}{l}-0.0128 \\
(0.0265)\end{array}$ & & \\
\hline Oct 2008 - Sep 2009 & & & $\begin{array}{l}-0.0026 \\
(0.0138)\end{array}$ & & & $\begin{array}{l}0.0150 \\
(0.0159)\end{array}$ & $\begin{array}{l}0.0137 \\
(0.0160)\end{array}$ \\
\hline Oct 2009 - Sep 2010 & & & $\begin{array}{l}0.0401^{* * *} \\
(0.0141)\end{array}$ & & & $\begin{array}{l}0.0613^{* * *} \\
(0.0167)\end{array}$ & $\begin{array}{l}0.0606^{* * *} \\
(0.0167)\end{array}$ \\
\hline Mediators Included & No & No & No & No & Yes & No & Yes \\
\hline
\end{tabular}

Notes: Point estimates are computed using linear probability model with individual fixed effects, adjusting for age fixed effects, time trend, seasonality, marital status, number of children in the household, and residency. Estimation models 1-5b are indicated by the column numbers (1) - (5b) at the top of the table. Model 1 is a business-cycle model, model 2 a collapse model, and model 3 a crisis model. Model 4 includes business cycles as well as the collapse, and model 5 includes business cycles as well as the crisis period. Models $4 b$ and $5 b$ furthermore include three individual-level mediators: individuals' unemployment, real monthly income, and real equity. Robust standard errors in parentheses. ${ }^{*} p<0.1,{ }^{* *} p<0.05,{ }^{* * *} p<0.01$. For the full sample $N=22,242,946$ and for the working-aged sample $N=17,539,631$, for the over 70 -year-old sample $N=2,661,037$. Average number of $1 \mathrm{HD}$ events per year is 728 for females. Coefficients are interpreted as changes (in percentage points) in the probability of an IHD event.

\section{Discussion}

In this analysis we exploit a unique circumstance, caused by a sudden economic collapse affecting the Icelandic population. We

find that the sign of the business-cycle coefficient tells the opposite story to those for the economic collapse (short term) and crisis

(long term) dummies. Those results would indicate that more difficult economic times over the business cycle, are generally beneficial for heart health, while the difficult times following the 2008 sudden economic downturn, were somewhat compromising 
for heart health. This implies that economic collapse has different (negative) effects on cardiovascular health than the (positive) impact of more typical business-cycle downturns, at least in Iceland. This is one of the most important finding of the analyses and is highlighted further by the fact that the estimated crisis effects hardly budge with the inclusion of aggregate unemployment rates in the model for short-term collapse analysis (i.e. by comparing models 2 and 4), and in the long-term analysis the coefficients for both the long-term crisis and the business cycle get larger in absolute terms (see comparison of results from models 1, 3 and 5) when estimated together. As hard economic times show opposite effects depending on context, the crisis thus has a suppressing effect on the business-cycle coefficient if not controlled for and vise versa. This indicates that those effects are not simply a part of a general business-cycle variation, but a distinct effect of this particular economic collapse and crisis in Iceland. Similarly, the coefficient for the aggregate unemployment rate hardly changes with the inclusion of the short-term collapse indicator, and increases in magnitude with the inclusion of long-term crisis variables. This is in contrast with results for the USA obtained by Ruhm (2016), where economic crises and less severe downturns are both associated with reductions in mortality rates. The different results found here and those of Ruhm's (2016) highlight the importance of conducting research in various contexts. Iceland and USA differ in many respects, for example in terms of structure of the welfare system, and hence the different results are perhaps not surprising, although the explanations are not clear. This is consistent with one of the main takeaways from this analysis; that the relationship between the aggregate economy and health are likely to be context specific, for example due to the fact that aggregate economic fluctuations come in various forms.

Icelandic men were more affected by unemployment and real income loss than women as a result of the economic crisis (Statistics Iceland, n.d.-a, g), and so it may not be surprising that the collapse and crisis often had larger effects for them. The statistically significant positive crisis effect on IHD events is uncovered for men in the first twelve months (models 3,5 , and $5 b$ ) and subsequent twelve months (models 5 and 5b). For women, similar results are found, but for the full sample and the eldest women, the coefficient for the latter twelve-month period is larger than the first. For working-aged women however, no crisis effect is found. Our results also show that the coefficients for the aggregate unemployment rate were larger in absolute terms for men than women, and statistically significant in most model specifications for all age groups studied, whereas for women it was only statistically significant in long-term analyses and seemingly driven by the oldest age group studied.

When comparing results from the full and age-restricted samples it seems that the found long-term effects are mostly driven by people over 70 years old. Although not statistically significant for the eldest males, the long-term crisis coefficients were larger in absolute value than for the working-aged males and the full sample. This is in accordance with previous research by Miller et al. 
(2009), where those mostly affected by a drop in the unemployment rate were those out of the labor force. The reasons for this are unclear, but indicate that possible pathways of found effects are not through the individuals' own labor-market experiences. This is further emphasized by results from the mediation analysis (full results in the appendix), showing that none of the possible mediators examined had a mediating effect, meaning that estimated effects from ambient economic conditions found here did not result from changes in individual-level equity, income, or employment.

Even for individuals remaining employed throughout the crisis, ambient conditions of a high unemployment rate could lead to increased stress which might be a trigger for a cardiovascular event. Findings from Eiriksdottir et al. (2015) would support such theory, as they attributed an increased risk of gestational hypertension to changes in aggregate unemployment rates during the economic collapse. However, when studying the probability of IHD in males, we find that a higher unemployment rate is associated with a lower probability of IHD (table 1). Moreover, although we do not have information on individuals' health behaviors, which are an important determinant of cardiovascular health, Asgeirsdottir et al. (2014a) and Asgeirsdottir et al. (2016b) found that the economic crisis led to both a short- and long-term general decrease in health-compromising behaviors, making our results of a long-term impact of the crisis all the more interesting.

A limitation of this study is the lack of medical history prior to the year 2000 , which prevents us from controlling for an individual's previous cardiovascular event, which obviously puts an individual at a higher risk for a subsequent cardiovascular event. Future research should aim to include such data. Another limitation is that the low number of IHD events in the sample reduces the statistical power of the analysis. Additional short-term analyses were performed using three one-month dummy variables (representing October 2008 - December 2008) instead of a single three-month dummy variable. For males, the November 2008 coefficient was positive and statistically significant, whereas those for October and December 2008 were both negative (but not significant). The sign reversal between the November and December parameter estimates is consistent with the possibility of "harvesting" whereby some IHD events were accelerated in time from December to November, rather than representing additional events.

To summarize, our results suggest that the 2008 collapse in Iceland increased IHD events, which contrasts with the beneficial estimated effects of more general (milder) downturns. However, despite the rather broad definition of a cardiovascular event employed here (including both fatal and non-fatal events), the estimated effects were fairly small in absolute and relative terms. This could reflect the strong Icelandic social insurance system, but its role was not examined here. The literature on business cycles 
and health is rich in many ways and highlights various forms of nuance, including differential effects depending on the various types of health outcomes, with a picture emerging that tells separate stories for physical and psychological health. Similarly, rich microdata has been increasingly used to examine various individual-level pathways and subgroups. Previous research using Icelandic data on the relationship between business cycles in general (Birgisdóttir \& Ásgeirsdóttir, 2017) or specific macroeconomic events that occurred well prior to the Great Recession (Ólafsdóttir et al., 2016) have found null effects or even a negative effect of increased economic activity on heart health. Based on those results alone, one might have presumed that the Great Recession was likely to be beneficial to heart health in the Icelandic population. However, recent results on the effects of the Great Recession have shown the contrary (Asgeirsdottir et al., 2014b; Birgisdottir et al., 2017; Eiriksdottir et al., 2015;

Gudjonsdottir et al., 2012). In the current study we provide an explanation for such differing results, i.e. that not all economic hard times are the same, and effects of specific macroeconomic events on health can be separated from the effects of general businesscycle fluctuations. Our results indicate that further focus on the variability in the types of aggregate economic conditions is warranted in future work. 


\section{References}

American Heart Association. (2015). Coronary Artery Disease - Coronary Heart Disease.

Arbab-Zadeh, A., Nakano, M., Virmani, R., \& Fuster, V. (2012). Acute Coronary Events. Circulation, 125, 1147-1156.

Ariizumi, H., \& Schirle, T. (2012). Are recessions really good for your health? Evidence from Canada. Social Science \& Medicine, 74, 1224-1231.

Arntz, H.-R., Müller-Nordhorn, J., \& Willich, S.N. (2001). Cold Monday mornings prove dangerous: epidemiology of sudden cardiac death. Current Opinion in Critical Care, 7, 139-144.

Asgeirsdottir, T.L., Berndsen, H.H., Gudmundsdottir, B.T., Gunnarsdottir, B.A., \& Halldorsdottir, H.J. (2016a). The effect of obesity, alcohol misuse and smoking on employment and hours worked: evidence from the Icelandic economic collapse. Review of Economics of the Household, 14, 313-335.

Asgeirsdottir, T.L., Corman, H., Noonan, K., Olafsdottir, T., \& Reichman, N.E. (2014a). Was the economic crisis of 2008 good for Icelanders? Impact on health behaviors. Economics \& Human Biology, 13, 1-19.

Asgeirsdottir, T.L., Corman, H., Noonan, K., \& Reichman, N.E. (2016b). Lifecycle effects of a recession on health behaviors: Boom, bust, and recovery in Iceland. Economics \& Human Biology, 20, 90-107.

Asgeirsdottir, T.L., Olafsdottir, T., \& Ragnarsdottir, D.O. (2014b). Business cycles, hypertension and cardiovascular disease: evidence from the Icelandic economic collapse. Blood Press, 23, 213-221.

Birgisdottir, K.H., Jonsson, S.H., \& Asgeirsdottir, T.L. (2017). Economic conditions, hypertension, and cardiovascular disease: analysis of the Icelandic economic collapse. Health Economics Review, 7, 20.

Birgisdóttir, K.H., \& Ásgeirsdóttir, T.L. (2017). Macroeconomic conditions and population health in Iceland. Demographic Research, 37, 769-852.

Cohen, M.C., Rohtla, K.M., Lavery, C.E., Muller, J.E., \& Mittleman, M.A. (1997). Meta-Analysis of the Morning Excess of Acute Myocardial Infarction and Sudden Cardiac Death. The American Journal of Cardiology, 79, 1512-1516.

Dimsdale, J.E. (2008). Psychological Stress and Cardiovascular Disease. Journal of the American College of Cardiology, $51,1237-1246$.

Directorate of labour. (n.d.). Vinnuafl og atvinnuleysi eftir ríkisborgararétti 2000-2017.

Economou, A., Nikolaou, A., \& Theodossiou, I. (2008). Are recessions harmful to health after all?; Evidence from the European Union. Journal of Economic Studies, 35, 368-384.

Eiriksdottir, V.H., Valdimarsdottir, U.A., Asgeirsdottir, T.L., Hauksdottir, A., Lund, S.H., Bjarnadottir, R.I., et al. (2015). Pregnancy-Induced Hypertensive Disorders before and after a National Economic Collapse: A Population Based Cohort Study. PLoS One, 10, e0138534.

Eliason, M., \& Storrie, D. (2009). Job loss is bad for your health - Swedish evidence on cause-specific hospitalization following involuntary job loss. Social Science \& Medicine, 68, 1396-1406.

Gerdtham, U.G., \& Johannesson, M. (2003). A note on the effect of unemployment on mortality. Journal of Health Economics, 22, 505-518.

Gerdtham, U.G., \& Johannesson, M. (2005). Business cycles and mortality: results from Swedish microdata. Social Science \& Medicine, 60, 205-218.

Gerdtham, U.G., \& Ruhm, C. (2006). Deaths rise in good economic times: Evidence from the OECD. Economics \& Human Biology, 4, 298-316.

Gudjonsdottir, G.R., Kristjansson, M., Olafsson, O., Arnar, D.O., Getz, L., Sigurdsson, J.A., et al. (2012). Immediate surge in female visits to the cardiac emergency department following the economic collapse in Iceland: an observational study. Emergency medicine journal, 29, 694-698.

Hauksdottir, A., McClure, C., Jonsson, S.H., Olafsson, O., \& Valdimarsdottir, U.A. (2013). Increased stress among women following an economic collapse - a prospective cohort study. American Journal of Epidemiology, 177, 979-988.

Jonsdottir, S., \& Asgeirsdottir, T.L. (2014). The effect of job loss on body weight during an economic collapse. The European Journal of Health Economics, 15, 567-576.

Leor, J., Poole, W.K., \& Kloner, R.A. (1996). Sudden cardiac death triggered by an earthquake. New England Journal of Medicine, 334, 413-419. 
Li, N., Wang, Y., Yu, L., Song, M., Wang, L., Ji, C., et al. (2017). Long-term effects of earthquake experience of young persons on cardiovascular disease risk factors. Archives of Medical Science : AMS, 13, 75-81.

Matthews, K.A., \& Gump, B.B. (2002). Chronic work stress and marital dissolution increase risk of posttrial mortality in men from the multiple risk factor intervention trial. Archives of Internal Medicine, 162, 309-315.

McClure, C.B., Valdimarsdottir, U.A., Hauksdottir, A., \& Kawachi, I. (2012). Economic crisis and smoking behaviour: prospective cohort study in Iceland. BMJ Open, 2.

Miller, D.L., Page, M.E., Stevens, A.H., \& Filipski, M. (2009). Why Are Recessions Good for Your Health? The American Economic Review, 99, 122-127.

Muller, J.E., Abela, G.S., Nesto, R.W., \& Tofler, G.H. (1994). Triggers, acute risk factors and vulnerable plaques: The lexicon of a new frontier. Journal of the American College of Cardiology, 23, 809-813.

OECD. (2016). Ageing and Employment Policies - Statistics on average effective age of retirement.

Olafsdottir, T., \& Asgeirsdottir, T.L. (2015). Gender differences in drinking behavior during an economic collapse: evidence from Iceland. Review of Economics of the Household, 1-27.

Olafsdottir, T., Hrafnkelsson, B., \& Asgeirsdottir, T.L. (2014). The Icelandic economic collapse, smoking, and the role of labor-market changes. The European Journal of Health Economics.

Olafsdottir, T., Hrafnkelsson, B., Thorgeirsson, G., \& Asgeirsdottir, T.L. (2016). The tax-free year in Iceland: A natural experiment to explore the impact of a short-term increase in labor supply on the risk of heart attacks. Journal of Health Economics, 49, 14-27.

Orth-Gomér, K., Wamala, S.P., Horsten, M., Schenck-Gustafsson, K., Schneiderman, N., \& Mittleman, M.A. (2000). Marital stress worsens prognosis in women with coronary heart disease: The stockholm female coronary risk study. JAMA, 284, 3008-3014.

Ólafsdóttir, T., Hrafnkelsson, B., Thorgeirsson, G., \& Ásgeirsdóttir, T.L. (2016). The tax-free year in Iceland: A natural experiment to explore the impact of a short-term increase in labor supply on the risk of heart attacks. Journal of Health Economics, 49, 14-27.

Ruhm, C. (2000). Are recessions good for your health? Quarterly journal of economics, 115, 617-650.

Ruhm, C. (2003). Good times make you sick. Journal of Health Economics, 22, 637-658.

Ruhm, C. (2004). Macroeconomic Conditions, Health and Mortality. National Bureau of Economic Research Working Paper Series, No. 11007.

Ruhm, C. (2005). Healthy living in hard times. Journal of Health Economics, 24, 341-363.

Ruhm, C. (2007). A healthy economy can break your heart. Demography, 44, 829-848.

Ruhm, C. (2015). Recessions, healthy no more? Journal of Health Economics, 42, 17-28.

Ruhm, C. (2016). Health Effects of Economic Crises. Health Economics, 25, 6-24.

Statistics Iceland. (n.d.-a). Activity rate, employment rate, underemployment rate and unemployment rate by quarters 2003-2017.

Statistics Iceland. (n.d.-b). Consumer price index from 1939.

Statistics Iceland. (n.d.-c). Employment, unemployment and labour force - Original Data - Montly 2003-2016.

Statistics Iceland. (n.d.-d). Enrolment at tertiary level by sex, age and domicile 1999-2015.

Statistics Iceland. (n.d.-e). Enrolment at upper secondary level by sex, age and domicile 1999-2015.

Statistics Iceland. (n.d.-f). Gross domestic product and Gross national income at constant prices 1980-2015.

Statistics Iceland. (n.d.-g). Income by sex and age 1990-2016.

Statistics Iceland. (n.d.-h). Labour market and wages.

Statistics Iceland. (n.d.-i). Liabilities, assets and net worth of individuals by family type, age and residence, 1997-2015.

Statistics Iceland. (n.d.-j). Residential property market price index from 2000.

Svensson, M. (2007). Do not go breaking your heart: Do economic upturns really increase heart attack mortality? Social Science \& Medicine, 65, 833-841.

Svensson, M. (2010). Economic upturns are good for your heart but watch out for accidents: a study on Swedish regional data 1976-2005. Applied Economics, 42, 615-625.

Tapia Granados, J.A. (2005). Recessions and mortality in Spain, 1980-1997. European Journal of Population-Revue Europeenne De Demographie, 21, 393-422. 
Tapia Granados, J.A., \& Ionides, E.L. (2017). Population health and the economy: Mortality and the Great Recession in Europe. Health Economics, n/a-n/a.

The Prime Minister's Office. (2008). Address to the Nation by H.E. Geir H. Haarde, Prime Minister of Iceland, October 6th 2008.

van den Berg, G.J., Gerdtham, U.G., von Hinke, S., Lindeboom, M., Lissdaniels, J., Sundquist, J., et al. (2017). Mortality and the business cycle: Evidence from individual and aggregated data. Journal of Health Economics, 56, 61-70. World Health Organization. (2014). The top 10 causes of death. 


\section{Appendix}

In this appendix, we present results using AMIs as the outcome variable, as well as results from our mediation analysis. Tables A1A7 contain results for men and tables A8-A14 for women. Model numbers refer to the models defined and explained in the Methods chapter of the main text. In the results for the mediation analysis, only models 1,4 , and 5 are included in the tables, as models 2 and 3 do not include any individual-level mediators. Models 1, 4, and 5 without mediators, as they appear in the main text, are included in the tables in the first column to better gage the changes in the collapse/crisis coefficients between models with and without mediators. Models that include mediators are labelled $1 \mathrm{~b}, 4 \mathrm{~b}$, and $5 \mathrm{~b}$ in tables A2-A7 and tables A9-A14.

\section{Males - AMI results}

From table A1 we can see that no statistically significant short-term or long-term relationship is found between the collapse/crisis and the probability of AMls in males, nor is there a detectable business-cycle effect in general. We include models $4 \mathrm{~b}$ and $5 \mathrm{~b}$ in table A1 for ease of comparison with table 1 in the main text, which includes results for IHD. The results from the mediation analysis, (tables A2-A4), reveal that although a person's own unemployment (tables A2 and A3) and real equity (table A2) are found to be positively and statistically significantly associated with the probability of AMls, neither of these individual factors have a mediating effect, as the short-term coefficients for the crisis do not change with their addition to the model. For the oldest age group, no coefficient for possible mediators was found to be statistically significant. 
Table A1: Estimates of the probability of an AMI event among men

\begin{tabular}{lccccccc} 
Full sample & $(1)$ & $(2)$ & $(3)$ & $(4)$ & $(4 \mathrm{~b})$ & $(5)$ & $(5 \mathrm{~b})$ \\
\hline \multirow{2}{*}{ Unemployment rate } & -0.0174 & & & -0.0173 & -0.0240 & -0.0239 & -0.0316 \\
& $(0.0187)$ & & & $(0.0187)$ & $(0.0189)$ & $(0.0246)$ & $(0.0248)$ \\
Oct 2008 - Dec 2008 & & 0.0013 & & 0.0012 & 0.0013 & & \\
& & $(0.0030)$ & & $(0.0030)$ & $(0.0030)$ & & \\
Oct 2008 - Sep 2009 & & & 0.0012 & & & 0.0020 & 0.0022 \\
& & & $(0.0015)$ & & & $(0.0018)$ & $(0.0018)$ \\
Oct 2009 - Sep 2010 & & & -0.0016 & & -0.0005 & -0.0005 \\
& & & $(0.0015)$ & & $(0.0018)$ & $(0.0018)$
\end{tabular}

Working-age sample

\begin{tabular}{|c|c|c|c|c|c|c|}
\hline Unemployment rate & $\begin{array}{c}-0.0149 \\
(0.0160)\end{array}$ & & $\begin{array}{l}-0.0147 \\
(0.0160)\end{array}$ & $\begin{array}{c}-0.0187 \\
(0.0161)\end{array}$ & $\begin{array}{c}-0.0172 \\
(0.0212)\end{array}$ & $\begin{array}{l}-0.0211 \\
(0.0213)\end{array}$ \\
\hline Oct 2008 - Dec 2008 & $\begin{array}{c}0.0024 \\
(0.0026)\end{array}$ & & $\begin{array}{c}0.0024 \\
(0.0026)\end{array}$ & $\begin{array}{l}0.0024 \\
(0.0026)\end{array}$ & & \\
\hline Oct 2008 - Sep 2009 & & $\begin{array}{c}0.0008 \\
(0.0013)\end{array}$ & & & $\begin{array}{c}0.0014 \\
(0.0015)\end{array}$ & $\begin{array}{c}0.0014 \\
(0.0015)\end{array}$ \\
\hline Oct 2009 - Sep 2010 & & $\begin{array}{c}-0.0015 \\
(0.0013)\end{array}$ & & & $\begin{array}{l}-0.0008 \\
(0.0015)\end{array}$ & $\begin{array}{c}-0.0008 \\
(0.0016)\end{array}$ \\
\hline
\end{tabular}

Over 70 years old sample

\begin{tabular}{|c|c|c|c|c|c|c|c|}
\hline Unemployment rate & $\begin{array}{c}-0.0311 \\
(0.1462)\end{array}$ & & & $\begin{array}{l}-0.0335 \\
(0.1463)\end{array}$ & $\begin{array}{c}-0.0455 \\
(0.1461)\end{array}$ & $\begin{array}{l}-0.0240 \\
(0.1936)\end{array}$ & $\begin{array}{l}-0.0491 \\
(0.1941)\end{array}$ \\
\hline Oct 2008 - Dec 2008 & & $\begin{array}{l}-0.0147 \\
(0.0230)\end{array}$ & & $\begin{array}{l}-0.0151 \\
(0.0230)\end{array}$ & $\begin{array}{c}-0.0141 \\
(0.0230)\end{array}$ & & \\
\hline Oct 2008 - Sep 2009 & & & $\begin{array}{c}0.0020 \\
(0.0121)\end{array}$ & & & $\begin{array}{c}0.0028 \\
(0.0140)\end{array}$ & $\begin{array}{c}0.0044 \\
(0.0141)\end{array}$ \\
\hline Oct 2009 - Sep 2010 & & & $\begin{array}{c}-0.0044 \\
(0.0118)\end{array}$ & & & $\begin{array}{l}-0.0035 \\
(0.0145)\end{array}$ & $\begin{array}{l}-0.0026 \\
(0.0145)\end{array}$ \\
\hline
\end{tabular}

Notes: Point estimates are computed using linear probability model with individual fixed effects, adjusting for age fixed effects, time trend, seasonality, marital status, number of children in the household, and residency. Estimation models 1-5b are indicated by the column numbers (1) - (5b) at the top of the table. Model 1 is a business-cycle model, model 2 a collapse model, and model 3 a crisis model. Model 4 includes business cycles as well as the collapse, and model 5 includes business cycles as well as the crisis period. Models $4 b$ and $5 b$ furthermore include three individual-level mediators: individuals' unemployment, real monthly income, and real equity. Robust standard errors in parentheses. ${ }^{*} p<0.1,{ }^{* *} p<0.05,{ }^{* * *} p<0.01$. For the full sample $N=22,570,569$, for the working-aged sample $N=18,349,379$, for the over 70 -year-old sample $N=2,104,560$. Average number of AMl events per year is 478 for males. Coefficients are interpreted as changes (in percentage points) in the probability of an AMI event. 
Table A2: Estimates of the probability of an AMI event among men (full sample) with mediators

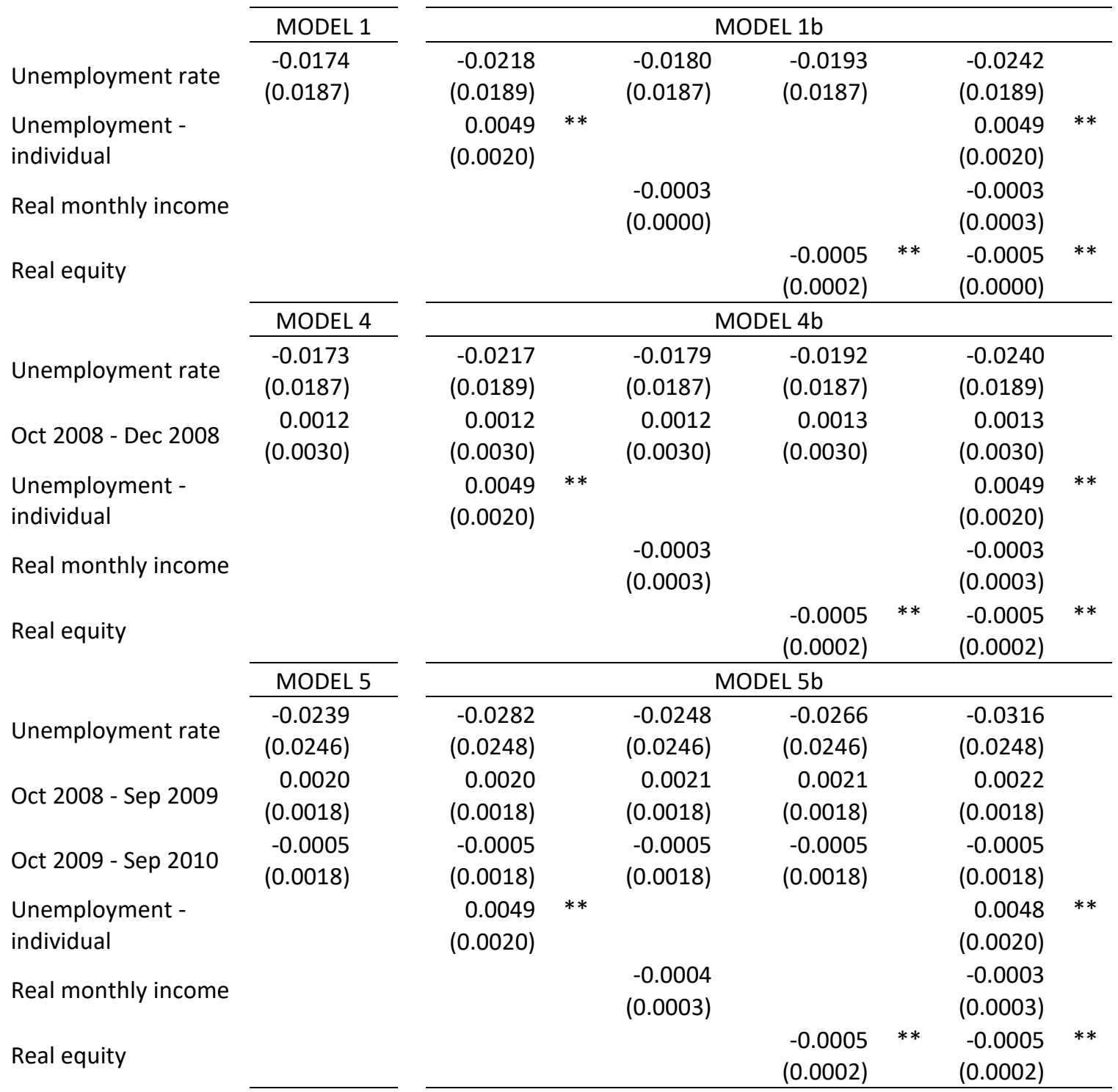

Notes: Robust standard errors in parentheses. ${ }^{*} p<0.1,{ }^{* *} p<0.05,{ }^{* *} p<0.01$. Point estimates are computed using linear probability model with individual fixed effects, adjusting for age fixed effects, time trend, seasonality, marital status, number of children in the household, and residency. Estimation models $1,1 b, 4,4 b, 5$, and $5 b$ are indicated by the panel headings. Model 1 is a business-cycle model, model 4 includes business cycles as well as the collapse, and model 5 includes business cycles as well as the crisis period. Models $1 b, 4 b$, and $5 b$ furthermore include the individual-level mediators: individuals' unemployment, real monthly income, and real equity, both added one at a time and in the last column all estimated simultaneously. N=22,570.569. Average number of AMI events per year is 478 for males. Coefficients are interpreted as changes (in percentage points) in the probability of an AMI event. 
Table A3: Estimates of the probability of an AMI event among working-aged men with mediators

\begin{tabular}{|c|c|c|c|c|c|c|}
\hline \multirow{3}{*}{ Unemployment rate } & \multirow{3}{*}{$\begin{array}{c}\text { MODEL } 1 \\
-0.0149 \\
(0.0160)\end{array}$} & \multirow{2}{*}{\multicolumn{5}{|c|}{ MODEL $1 b$}} \\
\hline & & & & & & \\
\hline & & $\begin{array}{r}-0.0190 \\
(0.0161)\end{array}$ & $\begin{array}{r}-0.0150 \\
(0.0160)\end{array}$ & $\begin{array}{l}-0.0149 \\
(0.0160)\end{array}$ & $\begin{array}{r}-0.0189 \\
(0.0161)\end{array}$ & \\
\hline \multirow{2}{*}{$\begin{array}{l}\text { Unemployment - } \\
\text { individual }\end{array}$} & & 0.0039 & $*$ & & 0.0039 & $*$ \\
\hline & & $(0.0021)$ & & & $(0.0021)$ & \\
\hline Real monthly income & & & $\begin{array}{r}0.0000 \\
(0.0002)\end{array}$ & & $\begin{array}{r}0.0000 \\
(0.0002)\end{array}$ & \\
\hline \multirow[t]{2}{*}{ Real equity } & & & & $\begin{array}{r}0.0000 \\
(0.0002)\end{array}$ & $\begin{array}{r}0.0000 \\
(0.0002)\end{array}$ & \\
\hline & MODEL 4 & \multicolumn{5}{|c|}{ MODEL 4b } \\
\hline Unemployment rate & $\begin{array}{r}-0.0147 \\
(0.0160)\end{array}$ & $\begin{array}{r}-0.0187 \\
(0.0161)\end{array}$ & $\begin{array}{r}-0.0147 \\
(0.0160)\end{array}$ & $\begin{array}{r}-0.0146 \\
(0.0160)\end{array}$ & $\begin{array}{r}-0.0187 \\
(0.0161)\end{array}$ & \\
\hline Oct 2008 - Dec 2008 & $\begin{array}{r}0.0024 \\
(0.0026)\end{array}$ & $\begin{array}{r}0.0024 \\
(0.0026)\end{array}$ & $\begin{array}{r}0.0024 \\
(0.0026)\end{array}$ & $\begin{array}{r}0.0024 \\
(0.0026)\end{array}$ & $\begin{array}{r}0.0024 \\
(0.0026)\end{array}$ & \\
\hline $\begin{array}{l}\text { Unemployment - } \\
\text { individual }\end{array}$ & & $\begin{array}{r}0.0039 \\
(0.0021)\end{array}$ & $*$ & & $\begin{array}{r}0.0039 \\
(0.0021)\end{array}$ & $*$ \\
\hline Real monthly income & & & $\begin{array}{r}0.0000 \\
(0.0002)\end{array}$ & & $\begin{array}{r}0.0000 \\
(0.0002)\end{array}$ & \\
\hline \multirow[t]{2}{*}{ Real equity } & & & & $\begin{array}{r}0.0000 \\
(0.0002) \\
\end{array}$ & $\begin{array}{r}0.0000 \\
(0.0002) \\
\end{array}$ & \\
\hline & MODEL 5 & \multicolumn{5}{|c|}{ MODEL 5b } \\
\hline Unemployment rate & $\begin{array}{r}-0.0172 \\
(0.0212)\end{array}$ & $\begin{array}{l}-0.0211 \\
(0.0213)\end{array}$ & $\begin{array}{l}-0.0172 \\
(0.0212)\end{array}$ & $\begin{array}{r}-0.0171 \\
(0.0212)\end{array}$ & $\begin{array}{r}-0.0211 \\
(0.0213)\end{array}$ & \\
\hline Oct 2008 - Sep 2009 & $\begin{array}{r}0.0014 \\
(0.0015)\end{array}$ & $\begin{array}{r}0.0014 \\
(0.0015)\end{array}$ & $\begin{array}{r}0.0014 \\
(0.0015)\end{array}$ & $\begin{array}{r}0.0014 \\
(0.0015)\end{array}$ & $\begin{array}{r}0.0014 \\
(0.0015)\end{array}$ & \\
\hline Oct 2009 - Sep 2010 & $\begin{array}{r}-0.0008 \\
(0.0015)\end{array}$ & $\begin{array}{r}-0.0008 \\
(0.0015)\end{array}$ & $\begin{array}{r}-0.0008 \\
(0.0015)\end{array}$ & $\begin{array}{r}-0.0008 \\
(0.0015)\end{array}$ & $\begin{array}{r}-0.0008 \\
(0.0016)\end{array}$ & \\
\hline $\begin{array}{l}\text { Unemployment - } \\
\text { individual }\end{array}$ & & $\begin{array}{r}0.0039 \\
(0.0021)\end{array}$ & $*$ & & $\begin{array}{r}0.0039 \\
(0.0021)\end{array}$ & * \\
\hline Real monthly income & & & $\begin{array}{r}0.0000 \\
(0.0002)\end{array}$ & & $\begin{array}{r}0.0000 \\
(0.0002)\end{array}$ & \\
\hline Real equity & & & & $\begin{array}{r}0.0099 \\
(0.0002) \\
\end{array}$ & $\begin{array}{r}0.0000 \\
(0.0002) \\
\end{array}$ & \\
\hline
\end{tabular}

Notes: Robust standard errors in parentheses. ${ }^{*} p<0.1,{ }^{* *} p<0.05,{ }^{* *} p<0.01$. Point estimates are computed using linear probability model with individual fixed effects, adjusting for age fixed effects, time trend, seasonality, marital status, number of children in the household, and residency. Estimation models $1,1 b, 4,4 b, 5$, and $5 b$ are indicated by the panel headings. Model 1 is a business-cycle model, model 4 includes business cycles as well as the collapse, and model 5 includes business cycles as well as the crisis period. Models $1 b, 4 b$, and $5 b$ furthermore include the individual-level mediators: individuals' unemployment, real monthly income, and real equity, both added one at a time and in the last column all estimated simultaneously. $N=18,349,379$. Average number of AMI events per year is 478 for males. Coefficients are interpreted as changes (in percentage points) in the probability of an AMI event. 
Table A4: Estimates of the probability of an AMI event among men aged over 70 with mediators

\begin{tabular}{|c|c|c|c|c|c|}
\hline \multirow{3}{*}{ Unemployment rate } & \multirow{3}{*}{$\begin{array}{c}\text { MODEL } 1 \\
-0.0311 \\
(0.1462)\end{array}$} & \multirow{2}{*}{\multicolumn{4}{|c|}{ MODEL 1b }} \\
\hline & & & & & \\
\hline & & $\begin{array}{r}-0.0311 \\
(0.1462)\end{array}$ & $\begin{array}{r}-0.0359 \\
(0.1461)\end{array}$ & $\begin{array}{r}-0.0390 \\
(0.1461)\end{array}$ & $\begin{array}{r}-0.0433 \\
(0.1460)\end{array}$ \\
\hline $\begin{array}{l}\text { Unemployment - } \\
\text { individual }\end{array}$ & & $\begin{array}{r}-0.0030 \\
(0.0303)\end{array}$ & & & $\begin{array}{r}-0.0011 \\
(0.0308)\end{array}$ \\
\hline Real monthly income & & & $\begin{array}{r}-0.0034 \\
(0.0023)\end{array}$ & & $\begin{array}{r}-0.0033 \\
(0.0023)\end{array}$ \\
\hline \multirow[t]{2}{*}{ Real equity } & & & & $\begin{array}{r}-0.0022 \\
(0.0019) \\
\end{array}$ & $\begin{array}{r}-0.0021 \\
(0.0019)\end{array}$ \\
\hline & MODEL 4 & \multicolumn{4}{|c|}{ MODEL 4b } \\
\hline Unemployment rate & $\begin{array}{r}-0.0335 \\
(0.1463)\end{array}$ & $\begin{array}{r}-0.0335 \\
(0.1463)\end{array}$ & $\begin{array}{r}-0.0382 \\
(0.1461)\end{array}$ & $\begin{array}{r}-0.0412 \\
(0.1462)\end{array}$ & $\begin{array}{r}-0.0455 \\
(0.1461)\end{array}$ \\
\hline Oct 2008 - Dec 2008 & $\begin{array}{r}-0.0151 \\
(0.0230)\end{array}$ & $\begin{array}{r}-0.0151 \\
(0.0230)\end{array}$ & $\begin{array}{r}-0.0148 \\
(0.0230)\end{array}$ & $\begin{array}{r}-0.0144 \\
(0.0230)\end{array}$ & $\begin{array}{r}-0.0141 \\
(0.0230)\end{array}$ \\
\hline $\begin{array}{l}\text { Unemployment - } \\
\text { individual }\end{array}$ & & $\begin{array}{r}0.0000 \\
(0.0304)\end{array}$ & & & $\begin{array}{r}0.0017 \\
(0.0307)\end{array}$ \\
\hline Real monthly income & & & $\begin{array}{r}-0.0034 \\
(0.0023)\end{array}$ & & $\begin{array}{r}-0.0033 \\
(0.0023)\end{array}$ \\
\hline \multirow[t]{2}{*}{ Real equity } & & & & $\begin{array}{r}-0.0021 \\
(0.0019) \\
\end{array}$ & $\begin{array}{r}-0.0020 \\
(0.0018) \\
\end{array}$ \\
\hline & MODEL 5 & \multicolumn{4}{|c|}{ MODEL 5b } \\
\hline Unemployment rate & $\begin{array}{r}-0.0240 \\
(0.1936)\end{array}$ & $\begin{array}{r}-0.0240 \\
(0.1936)\end{array}$ & $\begin{array}{r}-0.0333 \\
(0.1935)\end{array}$ & $\begin{array}{r}-0.0406 \\
(0.1942)\end{array}$ & $\begin{array}{r}-0.0491 \\
(0.1941)\end{array}$ \\
\hline Oct 2008 - Sep 2009 & $\begin{array}{r}0.0028 \\
(0.0140)\end{array}$ & $\begin{array}{r}0.0028 \\
(0.0140)\end{array}$ & $\begin{array}{r}0.0034 \\
(0.0140)\end{array}$ & $\begin{array}{r}0.0039 \\
(0.0141)\end{array}$ & $\begin{array}{r}0.0044 \\
(0.0141)\end{array}$ \\
\hline Oct 2009 - Sep 2010 & $\begin{array}{r}-0.0035 \\
(0.0145)\end{array}$ & $\begin{array}{r}-0.0035 \\
(0.0145)\end{array}$ & $\begin{array}{r}-0.0031 \\
(0.0145)\end{array}$ & $\begin{array}{r}-0.0029 \\
(0.0145)\end{array}$ & $\begin{array}{r}-0.0026 \\
(0.0145)\end{array}$ \\
\hline $\begin{array}{l}\text { Unemployment - } \\
\text { individual }\end{array}$ & & $\begin{array}{r}-0.0038 \\
(0.0305)\end{array}$ & & & $\begin{array}{r}-0.0021 \\
(0.0310)\end{array}$ \\
\hline Real monthly income & & & $\begin{array}{r}-0.0034 \\
(0.0023)\end{array}$ & & $\begin{array}{r}-0.0033 \\
(0.0023)\end{array}$ \\
\hline Real equity & & & & $\begin{array}{r}-0.0022 \\
(0.0019)\end{array}$ & $\begin{array}{r}-0.0021 \\
(0.0019)\end{array}$ \\
\hline
\end{tabular}

Notes: Robust standard errors in parentheses. ${ }^{*} p<0.1,{ }^{* *} p<0.05,{ }^{* *} p<0.01$. Point estimates are computed using linear probability model with individual fixed effects, adjusting for age fixed effects, time trend, seasonality, marital status, number of children in the household, and residency. Estimation models 1, 1b, 4, 4b, 5, and $5 b$ are indicated by the panel headings. Model 1 is a business-cycle model, model 4 includes business cycles as well as the collapse, and model 5 includes business cycles as well as the crisis period. Models $1 b, 4 b$, and $5 b$ furthermore include the individual-level mediators: individuals' unemployment, real monthly income, and real equity, both added one at a time and in the last column all estimated simultaneously. N=2,104,560. Average number of AMI events per year is 478 for males. Coefficients are interpreted as changes (in percentage points) in the probability of an AMI event. 


\section{Males - IHD results}

Results from the mediation analysis (table A5) show that when studying the whole sample, a person's own unemployment has a positive association with the probability of an IHD event. Interestingly, a person's own unemployment is not found to be statistically significantly related to the probability of IHDs in working-aged males (table A6). 
Table A5: Estimates of the probability of an IHD event among men (full sample) with mediators

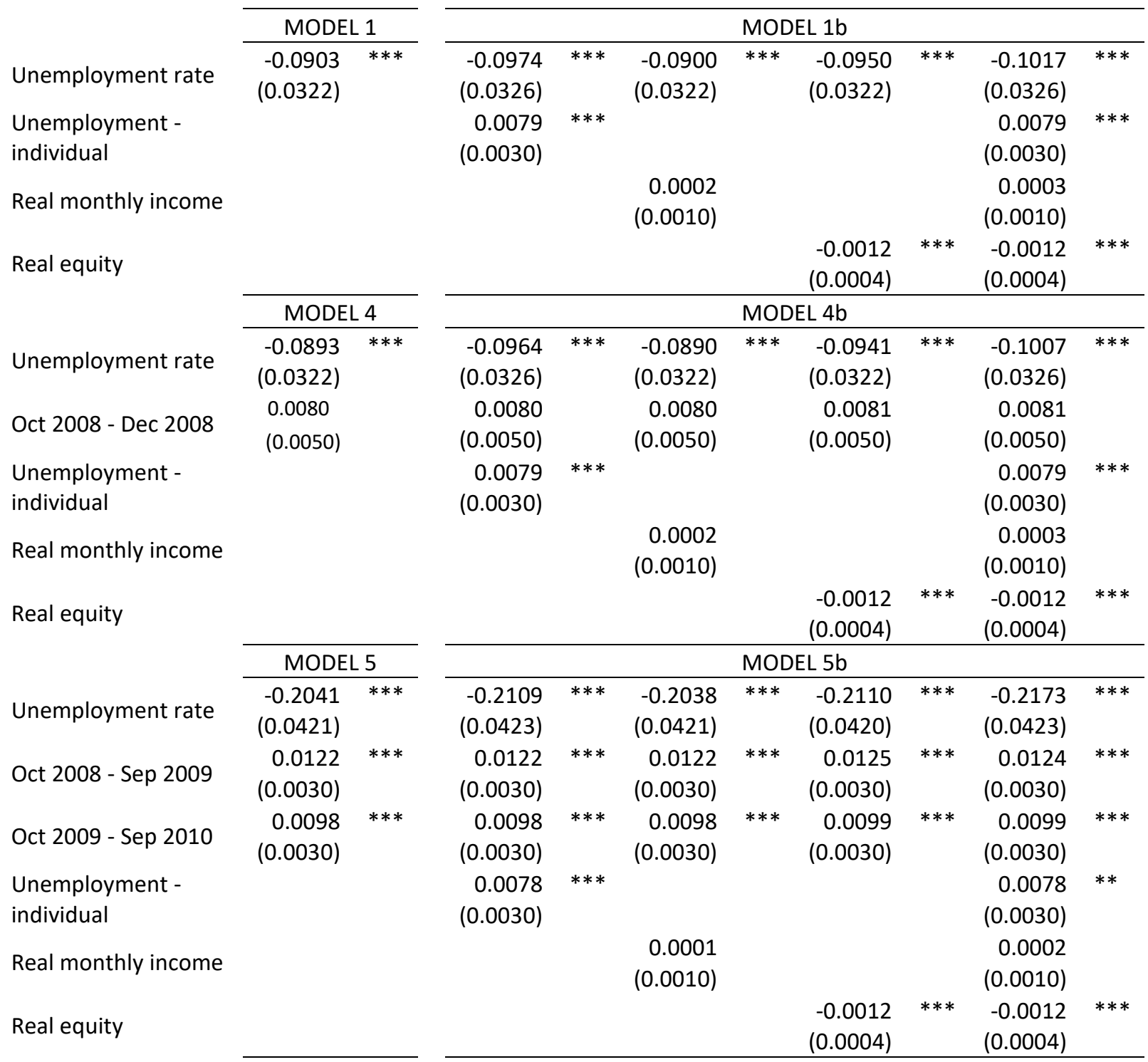

Notes: Robust standard errors in parentheses. ${ }^{*} p<0.1,{ }^{* *} p<0.05,{ }^{* *} p<0.01$. Point estimates are computed using linear probability model with individual fixed effects, adjusting for age fixed effects, time trend, seasonality, marital status, number of children in the household, and residency. Estimation models $1,1 b, 4,4 b, 5$, and $5 b$ are indicated by the panel headings. Model 1 is a business-cycle model, model 4 includes business cycles as well as the collapse, and model 5 includes business cycles as well as the crisis period. Models $1 b, 4 b$, and $5 b$ furthermore include the individual-level mediators: individuals' unemployment, real monthly income, and real equity, both added one at a time and in the last column all estimated simultaneously. $N=22,570.569$. Average number of IHD events per year is 1,339 for males. Coefficients are interpreted as changes (in percentage points) in the probability of an IHD event. 
Table A6: Estimates of the probability of an IHD event among working-aged men with mediators

Unemployment rate

Unemployment -

individual

Real monthly income

Real equity

Unemployment rate

Oct 2008 - Dec 2008

Unemployment -

individual

Real monthly income

Real equity

Unemployment rate

Oct 2008 - Sep 2009

Oct 2009 - Sep 2010

Unemployment -

individual

Real monthly income

Real equity

\begin{tabular}{c}
\hline MODEL 1 \\
\hline$-0.0639 * *$ \\
$(0.0277)$
\end{tabular}

\begin{tabular}{|c|c|c|}
\hline-0.0686 & $* *$ & -0.0620 \\
\hline$(0.0281)$ & & (0.0277) \\
\hline 0.0046 & & \\
\hline$(0.0032)$ & & \\
\hline
\end{tabular}

0.0010

(0.0010) MODEL $1 b$

$-0.0642$

(0.0277)

-0.0671
$(0.0280)$
0.0046

(0.0032)

0.0010

(0.0010)

$-0.0001 \quad-0.0001$

(0.0004) (0.0004)

\begin{tabular}{c}
\hline MODEL 4 \\
\hline$-0.0631 * *$ \\
$(0.0277)$ \\
0.0067 \\
$(0.0043)$
\end{tabular}

\begin{tabular}{|c|c|c|c|c|c|c|c|}
\hline \multicolumn{8}{|c|}{ MODEL 4b } \\
\hline-0.0678 & $* *$ & -0.0613 & $* *$ & -0.0634 & $* *$ & -0.0663 & $* *$ \\
\hline (0.0281) & & $(0.0277)$ & & (0.0277) & & $(0.0280)$ & \\
\hline 0.0067 & & 0.0067 & & 0.0067 & & 0.0067 & \\
\hline$(0.0043)$ & & $(0.0043)$ & & $(0.0043)$ & & $(0.0043)$ & \\
\hline 0.0046 & & & & & & 0.0046 & \\
\hline$(0.0032)$ & & & & & & $(0.0032)$ & \\
\hline & & 0.0010 & & & & 0.0010 & \\
\hline & & (0.0010) & & & & (0.0010) & \\
\hline & & & & -0.0001 & & -0.0001 & \\
\hline & & & & $(0.0004)$ & & $(0.0004)$ & \\
\hline
\end{tabular}

\begin{tabular}{rl}
\hline \multicolumn{2}{c}{ MODEL 5} \\
\hline-0.1521 & $* * *$ \\
$(0.0357)$ & \\
0.0095 & $* * *$ \\
$(0.0026)$ & \\
0.0076 & $* * *$ \\
$(0.0026)$ &
\end{tabular}

\begin{tabular}{|c|c|c|c|c|c|c|c|}
\hline \multicolumn{8}{|c|}{ MODEL 5b } \\
\hline-0.1565 & $* * *$ & -0.1495 & $* * *$ & -0.1526 & $* * *$ & -0.1546 & $* * *$ \\
\hline (0.0358) & & (0.0357) & & $(0.0356)$ & & (0.0359) & \\
\hline 0.0095 & $* * *$ & 0.0094 & $* * *$ & 0.0095 & $* * *$ & 0.0094 & $* * *$ \\
\hline$(0.0026)$ & & (0.0026) & & $(0.0026)$ & & $(0.0026)$ & \\
\hline 0.0076 & $* * *$ & 0.0075 & $* * *$ & 0.0076 & $* * *$ & 0.0075 & $* * *$ \\
\hline$(0.0026)$ & & (0.0026) & & $(0.0026)$ & & $(0.0026)$ & \\
\hline 0.0045 & & & & & & 0.0045 & \\
\hline$(0.0032)$ & & & & & & $(0.0032)$ & \\
\hline & & 0.0010 & & & & 0.0010 & \\
\hline & & (0.0010) & & & & (0.0010) & \\
\hline & & & & -0.0001 & & -0.0001 & \\
\hline & & & & (0.0004) & & $(0.0004)$ & \\
\hline
\end{tabular}

Notes: Robust standard errors in parentheses. ${ }^{*} p<0.1,{ }^{* *} p<0.05,{ }^{* *} p<0.01$. Point estimates are computed using linear probability model with individual fixed effects, adjusting for age fixed effects, time trend, seasonality, marital status, number of children in the household, and residency. Estimation models $1,1 b, 4,4 b, 5$, and $5 b$ are indicated by the panel headings. Model 1 is a business-cycle model, model 4 includes business cycles as well as the collapse, and model 5 includes business cycles as well as the crisis period. Models $1 b, 4 b$, and $5 b$ furthermore include the individual-level mediators: individuals' unemployment, real monthly income, and real equity, both added one at a time and in the last column all estimated simultaneously. $N=18,349,379$. Average number of IHD events per year is 1,339 for males. Coefficients are interpreted as changes (in percentage points) in the probability of an IHD event. 
Table A7: Estimates of the probability of an IHD event among men aged over 70 with mediators

\begin{tabular}{|c|c|c|c|c|c|c|c|c|}
\hline \multirow[b]{2}{*}{ Unemployment rate } & MODEL 1 & \multicolumn{7}{|c|}{ MODEL 1b } \\
\hline & $\begin{array}{r}-0.3696 \\
(0.2482)\end{array}$ & $\begin{array}{r}-0.3696 \\
(0.2482)\end{array}$ & $\begin{array}{r}-0.3789 \\
(0.2481)\end{array}$ & & $\begin{array}{r}-0.3875 \\
(0.2482)\end{array}$ & & $\begin{array}{r}-0.3960 \\
(0.2481)\end{array}$ & \\
\hline $\begin{array}{l}\text { Unemployment - } \\
\text { individual }\end{array}$ & & $\begin{array}{r}-0.0387 \\
(0.0591)\end{array}$ & & & & & $\begin{array}{r}-0.0345 \\
(0.0598)\end{array}$ & \\
\hline Real monthly income & & & $\begin{array}{r}-0.0067 \\
(0.0034)\end{array}$ & $*$ & & & $\begin{array}{r}-0.0064 \\
(0.0034)\end{array}$ & $*$ \\
\hline \multirow[t]{2}{*}{ Real equity } & & & & & $\begin{array}{r}-0.0049 \\
(0.0029) \\
\end{array}$ & $*$ & $\begin{array}{r}-0.0047 \\
(0.0029) \\
\end{array}$ & $*$ \\
\hline & MODEL 4 & \multicolumn{7}{|c|}{ MODEL 4b } \\
\hline Unemployment rate & $\begin{array}{r}-0.3686 \\
(0.2483)\end{array}$ & $\begin{array}{r}-0.3686 \\
(0.2483)\end{array}$ & $\begin{array}{r}-0.3779 \\
(0.2483)\end{array}$ & & $\begin{array}{r}-0.3863 \\
(0.2483)\end{array}$ & & $\begin{array}{r}-0.3947 \\
(0.2483)\end{array}$ & \\
\hline Oct 2008 - Dec 2008 & $\begin{array}{r}0.0062 \\
(0.0400)\end{array}$ & $\begin{array}{r}0.0063 \\
(0.0400)\end{array}$ & $\begin{array}{r}0.0068 \\
(0.0400)\end{array}$ & & $\begin{array}{r}0.0079 \\
(0.0400)\end{array}$ & & $\begin{array}{r}0.0084 \\
(0.0400)\end{array}$ & \\
\hline $\begin{array}{l}\text { Unemployment - } \\
\text { individual }\end{array}$ & & $\begin{array}{r}-0.0399 \\
(0.0596)\end{array}$ & & & & & $\begin{array}{r}-0.0362 \\
(0.0604)\end{array}$ & \\
\hline Real monthly income & & & $\begin{array}{r}-0.0067 \\
(0.0034)\end{array}$ & $*$ & & & $\begin{array}{r}-0.0065 \\
(0.0034)\end{array}$ & $*$ \\
\hline \multirow[t]{2}{*}{ Real equity } & & & & & $\begin{array}{r}-0.0049 \\
(0.0029) \\
\end{array}$ & $*$ & $\begin{array}{r}-0.0048 \\
(0.0029) \\
\end{array}$ & $*$ \\
\hline & MODEL 5 & \multicolumn{7}{|c|}{ MODEL 5b } \\
\hline Unemployment rate & $\begin{array}{r}-0.6405 * \\
(0.3351)\end{array}$ & $\begin{array}{r}-0.6405 \\
(0.3351)\end{array}$ & $\begin{array}{r}-0.6593 \\
(0.3352)\end{array}$ & $* *$ & $\begin{array}{r}-0.6803 \\
(0.3355)\end{array}$ & $* *$ & $\begin{array}{r}-0.6972 \\
(0.3355)\end{array}$ & $* *$ \\
\hline Oct 2008 - Sep 2009 & $\begin{array}{r}0.0286 \\
(0.0245)\end{array}$ & $\begin{array}{r}0.0286 \\
(0.0245)\end{array}$ & $\begin{array}{r}0.0297 \\
(0.0245)\end{array}$ & & $\begin{array}{r}0.0313 \\
(0.0245)\end{array}$ & & $\begin{array}{r}0.0323 \\
(0.0245)\end{array}$ & \\
\hline Oct 2009 - Sep 2010 & $\begin{array}{r}0.0238 \\
(0.0236)\end{array}$ & $\begin{array}{r}0.0238 \\
(0.0236)\end{array}$ & $\begin{array}{r}0.0245 \\
(0.0236)\end{array}$ & & $\begin{array}{r}0.0252 \\
(0.0236)\end{array}$ & & $\begin{array}{r}0.0258 \\
(0.0236)\end{array}$ & \\
\hline $\begin{array}{l}\text { Unemployment - } \\
\text { individual }\end{array}$ & & $\begin{array}{r}-0.0413 \\
(0.0598)\end{array}$ & & & & & $\begin{array}{r}-0.0373 \\
(0.0606)\end{array}$ & \\
\hline Real monthly income & & & $\begin{array}{r}-0.0069 \\
(0.0035)\end{array}$ & $* *$ & & & $\begin{array}{r}-0.0066 \\
(0.0034)\end{array}$ & $*$ \\
\hline Real equity & & & & & $\begin{array}{r}-0.0052 \\
(0.0029)\end{array}$ & $*$ & $\begin{array}{r}-0.0051 \\
(0.0029)\end{array}$ & $*$ \\
\hline
\end{tabular}

Notes: Robust standard errors in parentheses. ${ }^{*} p<0.1,{ }^{* *} p<0.05,{ }^{* *} p<0.01$. Point estimates are computed using linear probability model with individual fixed effects, adjusting for age fixed effects, time trend, seasonality, marital status, number of children in the household, and residency. Estimation models 1, 1b, 4, 4b, 5, and $5 b$ are indicated by the panel headings. Model 1 is a business-cycle model, model 4 includes business cycles as well as the collapse, and model 5 includes business cycles as well as the crisis period. Models $1 b, 4 b$, and $5 b$ furthermore include the individual-level mediators: individuals' unemployment, real monthly income, and real equity, both added one at a time and in the last column all estimated simultaneously. N=2,104,560. Average number of IHD events per year is 1,339 for males. Coefficients are interpreted as changes (in percentage points) in the probability of an IHD event. 


\section{Females - AMI results}

From table A8 we see that for both the full and age-restricted female samples, no short-term effects were found on AMIs, but long-term effects were found for all groups. For the full sample, effects are found for the first twelve months after the economic collapse, but for the working age population effects are found for up to twenty-four months. For the first twelve months the probability of an AMI was increased. In the working-age sample a negative, statistically significant relationship is found in the second year succeeding the economic collapse. The negative effect found almost offsets the positive effect found in the first twelve months - suggesting that the positive long-term effects found in the first twelve months may not represent extra cases of heart attacks in females during this period, but rather cases that were accelerated in time.

Of the possible individual-level mediators studied, the coefficient for real equity was consistently found to be negative and statistically significant for the full sample and working-aged sample (tables A9-A10). Although real equity seems to have an independent effect on the probability of AMIs in females, no mediating effects were found. 
Table A8: Estimates of the probability of an AMI event among women

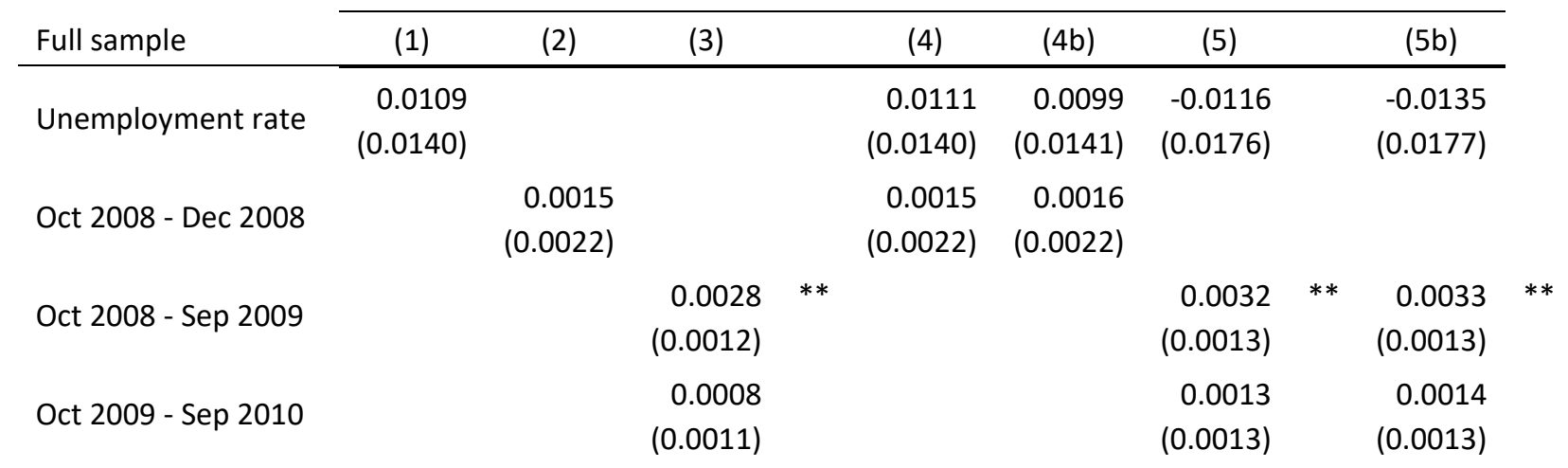

Working age sample

\begin{tabular}{|c|c|c|c|c|c|c|c|c|c|c|}
\hline Unemployment rate & $\begin{array}{r}0.0072 \\
(0.0086)\end{array}$ & & & & $\begin{array}{r}0.0073 \\
(0.0086)\end{array}$ & $\begin{array}{r}0.0072 \\
(0.0087)\end{array}$ & $\begin{array}{r}0.0081 \\
(0.0106)\end{array}$ & & $\begin{array}{r}0.0079 \\
(0.0106)\end{array}$ & \\
\hline Oct 2008 - Dec 2008 & & $\begin{array}{r}0.0003 \\
(0.0013)\end{array}$ & & & $\begin{array}{r}0.0004 \\
(0.0013)\end{array}$ & $\begin{array}{r}0.0004 \\
(0.0013)\end{array}$ & & & & \\
\hline Oct 2008 - Sep 2009 & & & $\begin{array}{r}0.0019 \\
(0.0008)\end{array}$ & $* *$ & & & $\begin{array}{r}0.0016 \\
(0.0009)\end{array}$ & $*$ & $\begin{array}{r}0.0017 \\
(0.0009)\end{array}$ & $*$ \\
\hline Oct 2009 - Sep 2010 & & & $\begin{array}{r}-0.0011 \\
(0.0006)\end{array}$ & $*$ & & & $\begin{array}{r}-0.0014 \\
(0.0008)\end{array}$ & $*$ & $\begin{array}{r}-0.0014 \\
(0.0008)\end{array}$ & $*$ \\
\hline
\end{tabular}

Over 70 years old sample

\begin{tabular}{|c|c|c|c|c|c|c|c|c|}
\hline Unemployment rate & $\begin{array}{r}0.0837 \\
(0.1033)\end{array}$ & & & $\begin{array}{r}0.0842 \\
(0.1033)\end{array}$ & $\begin{array}{r}0.0927 \\
(0.1035)\end{array}$ & $\begin{array}{r}-0.0720 \\
(0.1336)\end{array}$ & $\begin{array}{r}-0.0566 \\
(0.1342)\end{array}$ & \\
\hline Oct 2008 - Dec 2008 & $\begin{array}{r}0.0028 \\
(0.0162)\end{array}$ & & & $\begin{array}{r}0.0031 \\
(0.0162)\end{array}$ & $\begin{array}{r}0.0025 \\
(0.0162)\end{array}$ & & & \\
\hline Oct 2008 - Sep 2009 & & $\begin{array}{r}0.0062 \\
(0.0084)\end{array}$ & & & & $\begin{array}{r}0.0088 \\
(0.0097)\end{array}$ & $\begin{array}{r}0.0078 \\
(0.0097)\end{array}$ & $*$ \\
\hline Oct 2009 - Sep 2010 & & $\begin{array}{r}0.0167 \\
(0.0086)\end{array}$ & . & & & $\begin{array}{r}0.0199 \\
(0.0102)\end{array}$ & $\begin{array}{rr}* & 0.0194 \\
& (0.0103)\end{array}$ & \\
\hline
\end{tabular}

Notes: Point estimates are computed using linear probability model with individual fixed effects, adjusting for age fixed effects, time trend, seasonality, marital status, number of children in the household, and residency. Estimation models 1-5b are indicated by the column numbers (1) - (5b) at the top of the table. Model 1 is a business-cycle model, model 2 a collapse model, and model 3 a crisis model. Model 4 includes business cycles as well as the collapse, and model 5 includes business cycles as well as the crisis period. Models $4 b$ and $5 b$ furthermore include three individual-level mediators: individuals' unemployment, real monthly income, and real equity. Robust standard errors in parentheses. ${ }^{*} p<0.1,{ }^{* *} p<0.05,{ }^{* * *} p<0.01$. For the full sample $N=22,242,946$ and for the working-aged sample $N=17,539,631$, for the over 70 -year-old sample $N=2,661,037$. Average number of AMI events per year is 247 for females. Coefficients are interpreted as changes (in percentage points) in the probability of an AMI event. 
Table A9: Estimates of the probability of an AMI event among women (full sample) with mediators

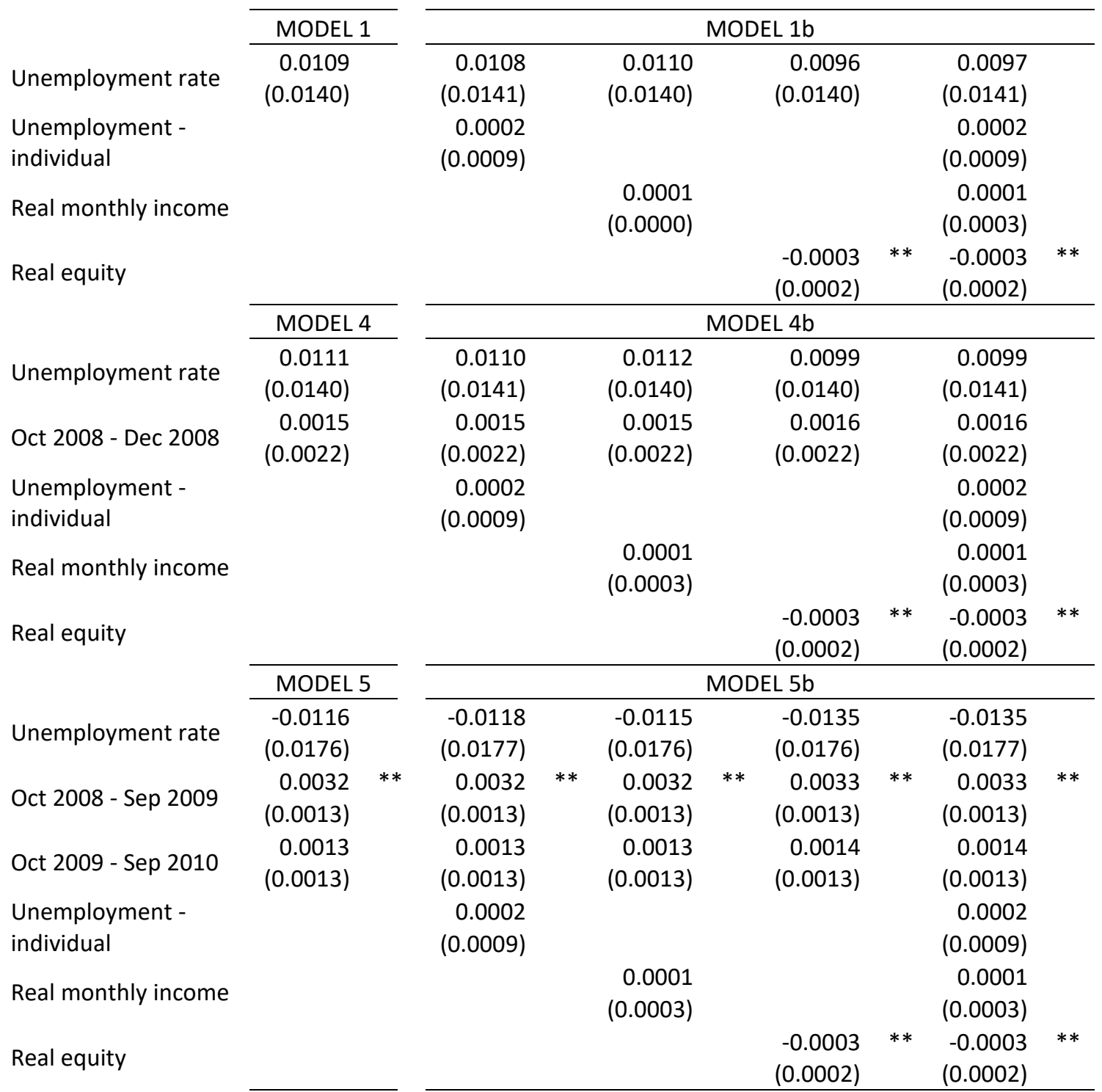

Notes: Robust standard errors in parentheses. ${ }^{*} p<0.1,{ }^{* *} p<0.05,{ }^{* *} p<0.01$. Point estimates are computed using linear probability model with individual fixed effects, adjusting for age fixed effects, time trend, seasonality, marital status, number of children in the household, and residency. Estimation models $1,1 b, 4,4 b, 5$, and $5 b$ are indicated by the panel headings. Model 1 is a business-cycle model, model 4 includes business cycles as well as the collapse, and model 5 includes business cycles as well as the crisis period. Models $1 b, 4 b$, and $5 b$ furthermore include the individual-level mediators: individuals' unemployment, real monthly income, and real equity, both added one at a time and in the last column all estimated simultaneously. $N=22,242,946$. Average number of $A M I$ events per year is 247 for females. Coefficients are interpreted as changes (in percentage points) in the probability of an AMI event. 
Table A10: Estimates of the probability of an AMI event among working-aged women with mediators

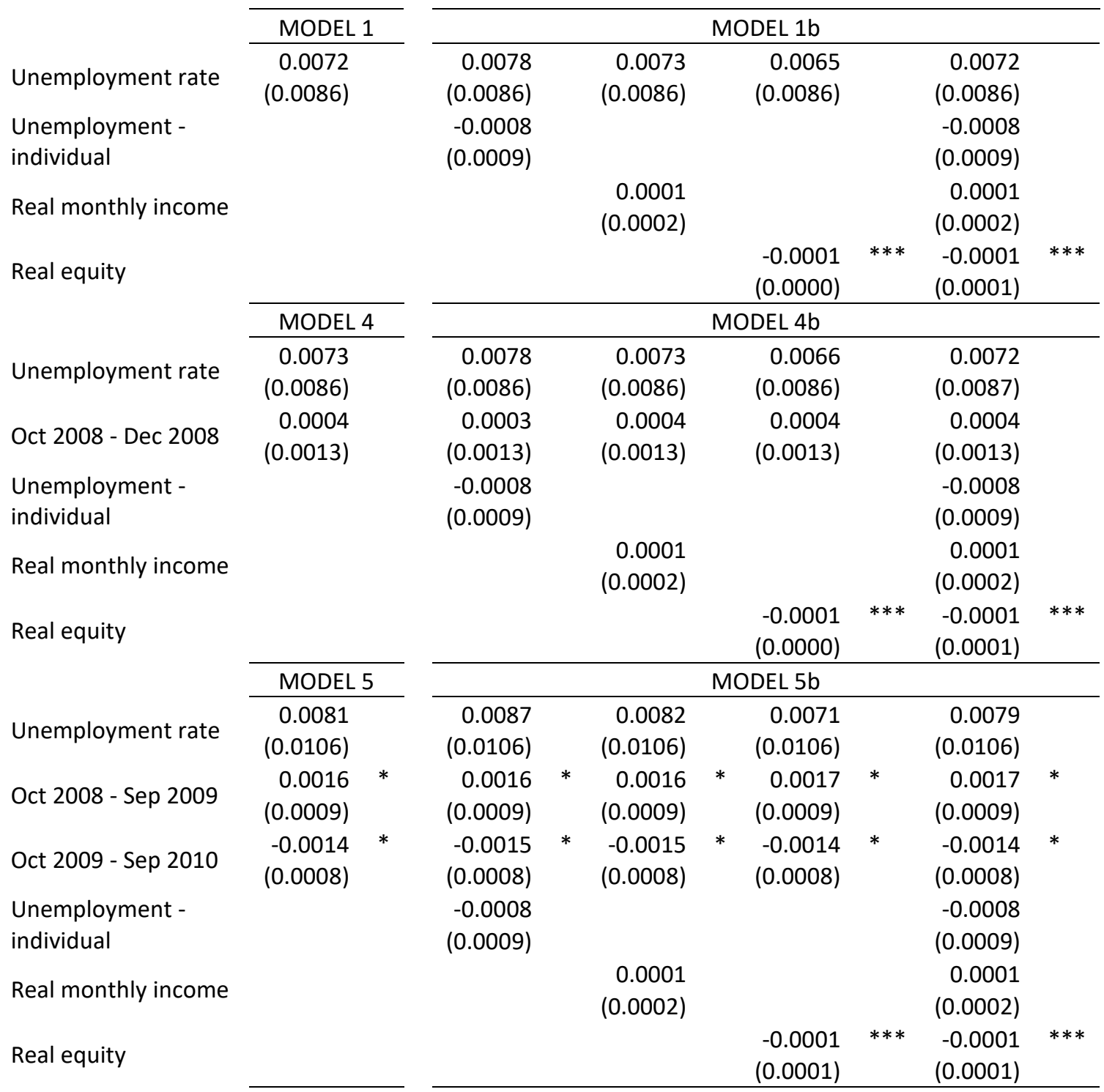

Notes: Robust standard errors in parentheses. ${ }^{*} p<0.1,{ }^{* *} p<0.05,{ }^{* *} p<0.01$. Point estimates are computed using linear probability model with individual fixed effects, adjusting for age fixed effects, time trend, seasonality, marital status, number of children in the household, and residency. Estimation models $1,1 b, 4,4 b, 5$, and $5 b$ are indicated by the panel headings. Model 1 is a business-cycle model, model 4 includes business cycles as well as the collapse, and model 5 includes business cycles as well as the crisis period. Models $1 b, 4 b$, and $5 b$ furthermore include the individual-level mediators: individuals' unemployment, real monthly income, and real equity, both added one at a time and in the last column all estimated simultaneously. N=17,539,631. Average number of AMI events per year is 247 for females. Coefficients are interpreted as changes (in percentage points) in the probability of an AMI event. 
Table A11: Estimates of the probability of an AMI event among women aged over 70 with mediators

\begin{tabular}{|c|c|c|c|c|c|c|}
\hline \multirow{3}{*}{\multicolumn{2}{|c|}{\begin{tabular}{lr}
\cline { 2 - 2 } & \multicolumn{1}{c}{ MODEL 1 } \\
\cline { 2 - 2 } Unemployment rate & 0.0837 \\
& $(0.1033)$
\end{tabular}}} & \multirow{2}{*}{\multicolumn{5}{|c|}{ MODEL 1}} \\
\hline & & & & & & \\
\hline & & $\begin{array}{r}0.0837 \\
(0.1033)\end{array}$ & $\begin{array}{r}0.0843 \\
(0.1033)\end{array}$ & $\begin{array}{r}0.0918 \\
(0.1035)\end{array}$ & \multicolumn{2}{|l|}{$\begin{array}{r}0.0923 \\
(0.1035)\end{array}$} \\
\hline $\begin{array}{l}\text { Unemployment - } \\
\text { individual }\end{array}$ & & $\begin{array}{r}-0.0084 \\
(0.0477)\end{array}$ & & & $\begin{array}{r}-0.0083 \\
(0.0476)\end{array}$ & \\
\hline Real monthly income & & & $\begin{array}{r}0.0006 \\
(0.0011)\end{array}$ & & $\begin{array}{r}0.0005 \\
(0.0011)\end{array}$ & \\
\hline \multirow[t]{2}{*}{ Real equity } & & & & $\begin{array}{r}0.0020 \\
(0.0014) \\
\end{array}$ & $\begin{array}{r}0.0020 \\
(0.0014) \\
\end{array}$ & \\
\hline & MODEL 4 & \multicolumn{5}{|c|}{ MODEL 4b } \\
\hline Unemployment rate & $\begin{array}{r}0.0842 \\
(0.1033)\end{array}$ & $\begin{array}{r}0.0842 \\
(0.1033)\end{array}$ & $\begin{array}{r}0.0848 \\
(0.1033)\end{array}$ & $\begin{array}{r}0.0922 \\
(0.1035)\end{array}$ & $\begin{array}{r}0.0927 \\
(0.1035)\end{array}$ & \\
\hline Oct 2008 - Dec 2008 & $\begin{array}{r}0.0031 \\
(0.0162)\end{array}$ & $\begin{array}{r}0.0031 \\
(0.0162)\end{array}$ & $\begin{array}{r}0.0031 \\
(0.0162)\end{array}$ & $\begin{array}{r}0.0026 \\
(0.0162)\end{array}$ & $\begin{array}{r}0.0025 \\
(0.0162)\end{array}$ & \\
\hline $\begin{array}{l}\text { Unemployment - } \\
\text { individual }\end{array}$ & & $\begin{array}{r}-0.0083 \\
(0.0477)\end{array}$ & & & $\begin{array}{r}-0.0082 \\
(0.0476)\end{array}$ & \\
\hline Real monthly income & & & $\begin{array}{r}0.0006 \\
(0.0011)\end{array}$ & & $\begin{array}{r}0.0005 \\
(0.0011)\end{array}$ & \\
\hline \multirow[t]{2}{*}{ Real equity } & & & & $\begin{array}{r}0.0020 \\
(0.0014) \\
\end{array}$ & $\begin{array}{r}0.0020 \\
(0.0014) \\
\end{array}$ & \\
\hline & MODEL 5 & \multicolumn{5}{|c|}{ MODEL 5b } \\
\hline Unemployment rate & $\begin{array}{r}-0.0720 \\
(0.1336)\end{array}$ & $\begin{array}{r}-0.0721 \\
(0.1336)\end{array}$ & $\begin{array}{r}-0.0710 \\
(0.1336)\end{array}$ & $\begin{array}{r}-0.0574 \\
(0.1342)\end{array}$ & $\begin{array}{r}-0.0566 \\
(0.1342)\end{array}$ & \\
\hline Oct 2008 - Sep 2009 & $\begin{array}{r}0.0088 \\
(0.0097)\end{array}$ & $\begin{array}{r}0.0088 \\
(0.0097)\end{array}$ & $\begin{array}{r}0.0087 \\
(0.0097)\end{array}$ & $\begin{array}{r}0.0079 \\
(0.0097)\end{array}$ & $\begin{array}{r}0.0078 \\
(0.0097)\end{array}$ & \\
\hline Oct 2009 - Sep 2010 & $\begin{array}{r}0.0199 \\
(0.0102)\end{array}$ & $\begin{array}{r}0.0199 \\
(0.0102)\end{array}$ & $\begin{array}{rr}* & 0.0199 \\
& (0.0102)\end{array}$ & $\begin{array}{r}0.0194 \\
(0.0103)\end{array}$ & $\begin{array}{rr}* & 0.0194 \\
& (0.0103)\end{array}$ & * \\
\hline $\begin{array}{l}\text { Unemployment - } \\
\text { individual }\end{array}$ & & $\begin{array}{r}-0.0176 \\
(0.0472)\end{array}$ & & & $\begin{array}{r}-0.0171 \\
(0.0471)\end{array}$ & \\
\hline Real monthly income & & & $\begin{array}{r}0.0005 \\
(0.0011)\end{array}$ & & $\begin{array}{r}0.0005 \\
(0.0011)\end{array}$ & \\
\hline Real equity & & & & $\begin{array}{r}0.0019 \\
(0.0014) \\
\end{array}$ & $\begin{array}{r}0.0019 \\
(0.0014) \\
\end{array}$ & \\
\hline
\end{tabular}

Notes: Robust standard errors in parentheses. ${ }^{*} p<0.1,{ }^{* *} p<0.05,{ }^{* *} p<0.01$. Point estimates are computed using linear probability model with individual fixed effects, adjusting for age fixed effects, time trend, seasonality, marital status, number of children in the household, and residency. Estimation models $1,1 b, 4,4 b, 5$, and $5 b$ are indicated by the panel headings. Model 1 is a business-cycle model, model 4 includes business cycles as well as the collapse, and model 5 includes business cycles as well as the crisis period. Models $1 b, 4 b$, and $5 b$ furthermore include the individual-level mediators: individuals' unemployment, real monthly income, and real equity, both added one at a time and in the last column all estimated simultaneously. $N=2,661,037$. Average number of $A M I$ events per year is 247 for females. Coefficients are interpreted as changes (in percentage points) in the probability of an AMI event. 


\section{Females - IHD results}

For working-aged females a person's own unemployment was found to be independently related to the probability of IHD (no mediating effects), where the coefficient was always negative and statistically significant, indicating that over the study period a person's own unemployment might be beneficial to heart health (table A13). For the full sample, real equity similarly was negative and independently related to the probability of IHD without mediating any effects (table A12). 
Table A12: Estimates of the probability of an IHD event among women (full sample) with mediators

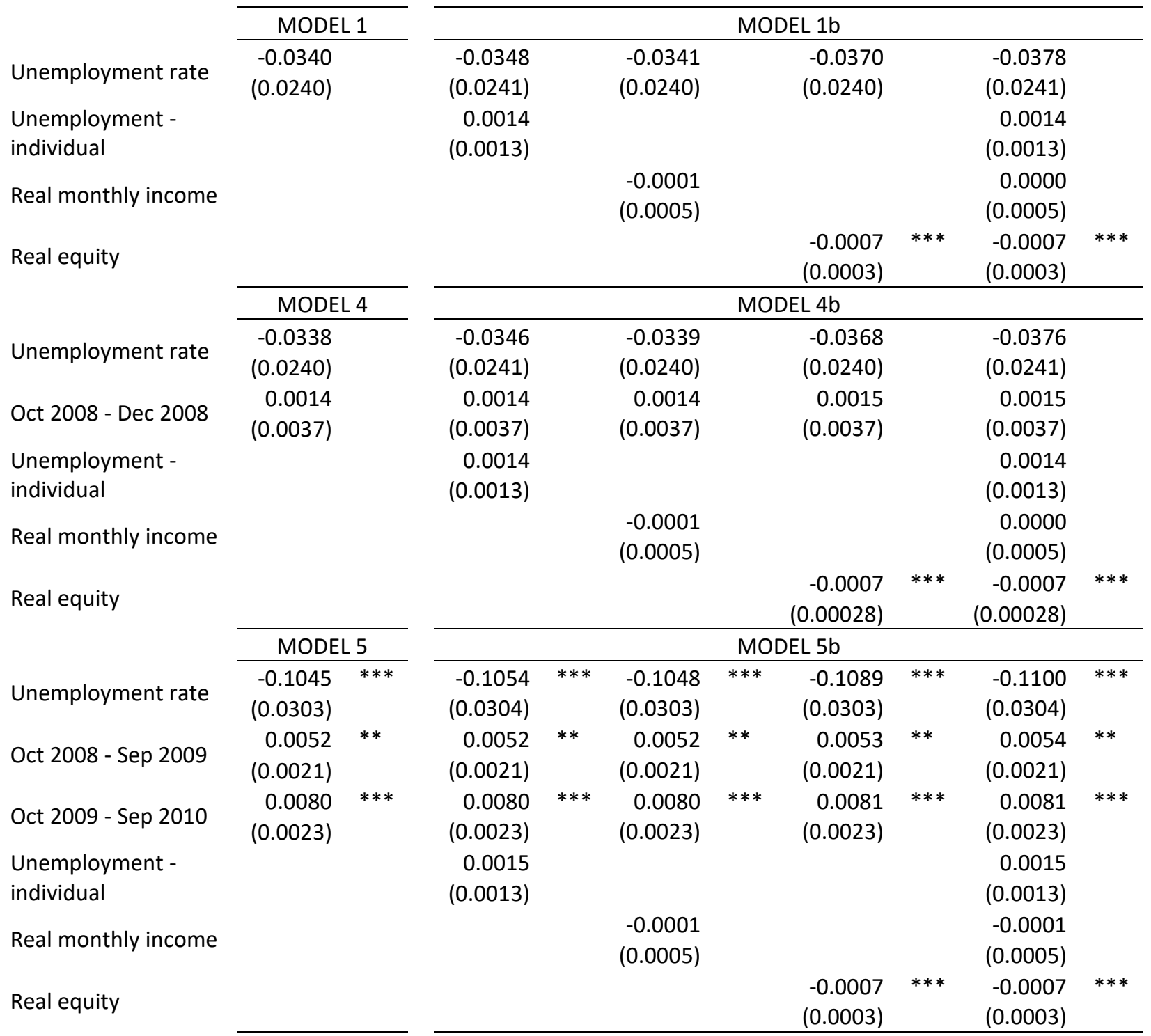

Notes: Robust standard errors in parentheses. ${ }^{*} p<0.1,{ }^{* *} p<0.05,{ }^{* *} p<0.01$. Point estimates are computed using linear probability model with individual fixed effects, adjusting for age fixed effects, time trend, seasonality, marital status, number of children in the household, and residency. Estimation models $1,1 b, 4,4 b, 5$, and $5 b$ are indicated by the panel headings. Model 1 is a business-cycle model, model 4 includes business cycles as well as the collapse, and model 5 includes business cycles as well as the crisis period. Models $1 b, 4 b$, and $5 b$ furthermore include the individual-level mediators: individuals' unemployment, real monthly income, and real equity, both added one at a time and in the last column all estimated simultaneously. $N=22,242,946$. Average number of IHD events per year is 728 for females. Coefficients are interpreted as changes (in percentage points) in the probability of an IHD event. 
Table A13: Estimates of the probability of an IHD event among working-aged women with mediators

\begin{tabular}{|c|c|c|c|c|c|c|c|}
\hline \multirow{3}{*}{ Unemployment rate } & \multirow{3}{*}{$\begin{array}{c}\text { MODEL } 1 \\
-0.0165 \\
(0.0155)\end{array}$} & \multirow{2}{*}{\multicolumn{6}{|c|}{ MODEL 1b }} \\
\hline & & & & & & & \\
\hline & & $\begin{array}{r}-0.0148 \\
(0.0156)\end{array}$ & & $\begin{array}{r}-0.0162 \\
(0.0154)\end{array}$ & $\begin{array}{r}-0.0173 \\
(0.0155)\end{array}$ & $\begin{array}{r}-0.0154 \\
(0.0156)\end{array}$ & \\
\hline $\begin{array}{l}\text { Unemployment - } \\
\text { individual }\end{array}$ & & $\begin{array}{r}-0.0026 \\
(0.0013)\end{array}$ & $* *$ & & & $\begin{array}{r}-0.0026 \\
(0.0013)\end{array}$ & $* *$ \\
\hline Real monthly income & & & & $\begin{array}{r}0.0003 \\
(0.0005)\end{array}$ & & $\begin{array}{r}0.0003 \\
(0.0005)\end{array}$ & \\
\hline \multirow[t]{2}{*}{ Real equity } & & & & & $\begin{array}{r}-0.0002 \\
(0.0001)\end{array}$ & $\begin{array}{r}-0.0002 \\
(0.0001)\end{array}$ & \\
\hline & MODEL 4 & \multicolumn{6}{|c|}{ MODEL 4b } \\
\hline Unemployment rate & $\begin{array}{r}-0.0147 \\
(0.0156)\end{array}$ & $\begin{array}{r}-0.0147 \\
(0.0156)\end{array}$ & & $\begin{array}{r}-0.0161 \\
(0.0155)\end{array}$ & $\begin{array}{r}-0.0172 \\
(0.0155)\end{array}$ & $\begin{array}{r}-0.0152 \\
(0.0156)\end{array}$ & \\
\hline Oct 2008 - Dec 2008 & $\begin{array}{r}0.0009 \\
(0.0024)\end{array}$ & $\begin{array}{r}0.0009 \\
(0.0024)\end{array}$ & & $\begin{array}{r}0.0009 \\
(0.0024)\end{array}$ & $\begin{array}{r}0.0009 \\
(0.0024)\end{array}$ & $\begin{array}{r}0.0009 \\
(0.0024)\end{array}$ & \\
\hline $\begin{array}{l}\text { Unemployment - } \\
\text { individual }\end{array}$ & & $\begin{array}{r}-0.0026 \\
(0.0013)\end{array}$ & $* *$ & & & $\begin{array}{r}-0.0026 \\
(0.0013)\end{array}$ & $* *$ \\
\hline Real monthly income & & & & $\begin{array}{r}0.0003 \\
(0.0005)\end{array}$ & & $\begin{array}{r}0.0003 \\
(0.0005)\end{array}$ & \\
\hline \multirow[t]{2}{*}{ Real equity } & & & & & $\begin{array}{r}-0.0002 \\
(0.0001)\end{array}$ & $\begin{array}{r}-0.0002 \\
(0.0001)\end{array}$ & \\
\hline & MODEL 5 & \multicolumn{6}{|c|}{ MODEL 5b } \\
\hline Unemployment rate & $\begin{array}{r}-0.0232 \\
(0.0198)\end{array}$ & $\begin{array}{r}-0.0213 \\
(0.0199)\end{array}$ & & $\begin{array}{r}-0.0227 \\
(0.0198)\end{array}$ & $\begin{array}{r}-0.0243 \\
(0.0198)\end{array}$ & $\begin{array}{r}-0.0220 \\
(0.0199)\end{array}$ & \\
\hline Oct 2008 - Sep 2009 & $\begin{array}{r}0.0013 \\
(0.0014)\end{array}$ & $\begin{array}{r}0.0013 \\
(0.0014)\end{array}$ & & $\begin{array}{r}0.0013 \\
(0.0014)\end{array}$ & $\begin{array}{r}0.0014 \\
(0.0014)\end{array}$ & $\begin{array}{r}0.0013 \\
(0.0014)\end{array}$ & \\
\hline Oct 2009 - Sep 2010 & $\begin{array}{r}0.0001 \\
(0.0014)\end{array}$ & $\begin{array}{r}0.0001 \\
(0.0014)\end{array}$ & & $\begin{array}{r}0.0001 \\
(0.0014)\end{array}$ & $\begin{array}{r}0.0001 \\
(0.0014)\end{array}$ & $\begin{array}{r}0.0001 \\
(0.0014)\end{array}$ & \\
\hline $\begin{array}{l}\text { Unemployment - } \\
\text { individual }\end{array}$ & & $\begin{array}{r}-0.0026 \\
(0.0013)\end{array}$ & $* *$ & & & $\begin{array}{r}-0.0026 \\
(0.0013)\end{array}$ & $* *$ \\
\hline Real monthly income & & & & $\begin{array}{r}0.0003 \\
(0.0005)\end{array}$ & & $\begin{array}{r}0.0003 \\
(0.0005)\end{array}$ & \\
\hline Real equity & & & & & $\begin{array}{r}-0.0002 \\
(0.0001)\end{array}$ & $\begin{array}{r}-0.0002 \\
(0.0001)\end{array}$ & \\
\hline
\end{tabular}

Notes: Robust standard errors in parentheses. ${ }^{*} p<0.1,{ }^{* *} p<0.05,{ }^{* *} p<0.01$. Point estimates are computed using linear probability model with individual fixed effects, adjusting for age fixed effects, time trend, seasonality, marital status, number of children in the household, and residency. Estimation models $1,1 b, 4,4 b, 5$, and $5 b$ are indicated by the panel headings. Model 1 is a business-cycle model, model 4 includes business cycles as well as the collapse, and model 5 includes business cycles as well as the crisis period. Models $1 b, 4 b$, and $5 b$ furthermore include the individual-level mediators: individuals' unemployment, real monthly income, and real equity, both added one at a time and in the last column all estimated simultaneously. $N=17,539,631$. Average number of $I H D$ events per year is 728 for females. Coefficients are interpreted as changes (in percentage points) in the probability of an IHD event. 
Table A14: Estimates of the probability of an IHD event among women aged over 70 with mediators

\begin{tabular}{|c|c|c|c|c|c|c|c|c|c|c|}
\hline \multirow{4}{*}{ Unemployment rate } & \multirow{2}{*}{\multicolumn{2}{|c|}{ MODEL 1}} & \multirow{2}{*}{\multicolumn{8}{|c|}{ MODEL 1}} \\
\hline & & & & & & & & & & \\
\hline & \multirow{2}{*}{\multicolumn{2}{|c|}{$\begin{array}{r}-0.0565 \\
(0.1730)\end{array}$}} & \multirow{2}{*}{\multicolumn{2}{|c|}{$\begin{array}{r}-0.0565 \\
(0.1730)\end{array}$}} & \multirow{2}{*}{$\begin{array}{r}-0.0573 \\
(0.1730)\end{array}$} & & \multirow{2}{*}{$\begin{array}{r}-0.0437 \\
(0.1733)\end{array}$} & \\
\hline & & & & & & & & & $(0.1733)$ & \\
\hline Unemployment - & & & -0.1015 & & & & & & -0.1013 & \\
\hline individual & & & $(0.1219)$ & & & & & & $(0.1215)$ & \\
\hline \multirow{2}{*}{ Real monthly income } & & & & & -0.0008 & & & & -0.0009 & \\
\hline & & & & & $(0.0013)$ & & & & $(0.0013)$ & \\
\hline \multirow{3}{*}{ Real equity } & & & & & & & 0.0031 & & 0.0031 & \\
\hline & & & & & & & $(0.0026)$ & & $(0.0026)$ & \\
\hline & MODE & & & & & MOL & $\mathrm{L} 4 \mathrm{~b}$ & & & \\
\hline \multirow{2}{*}{ Unemployment rate } & -0.0584 & & -0.0585 & & -0.0592 & & -0.0457 & & -0.0466 & \\
\hline & $(0.1732)$ & & $(0.1732)$ & & $(0.1732)$ & & $(0.1735)$ & & $(0.1735)$ & \\
\hline \multirow{2}{*}{ Oct 2008 - Dec 2008} & -0.0120 & & -0.0120 & & -0.0120 & & -0.0129 & & -0.0128 & \\
\hline & $(0.0265)$ & & $(0.0265)$ & & $(0.0265)$ & & $(0.0265)$ & & $(0.0265)$ & \\
\hline \multirow{2}{*}{$\begin{array}{l}\text { Unemployment - } \\
\text { individual }\end{array}$} & & & -0.1019 & & & & & & -0.1018 & \\
\hline & & & $(0.1218)$ & & & & & & $(0.1215)$ & \\
\hline \multirow{2}{*}{ Real monthly income } & & & & & -0.0008 & & & & -0.0009 & \\
\hline & & & & & $(0.0013)$ & & & & $(0.0013)$ & \\
\hline \multirow{3}{*}{ Real equity } & & & & & & & 0.0031 & & 0.0032 & \\
\hline & & & & & & & $(0.0026)$ & & $(0.0026)$ & \\
\hline & MODE & & & & & MOL & $5 b$ & & & \\
\hline \multirow{2}{*}{ Unemployment rate } & -0.4802 & $* *$ & -0.4804 & $* *$ & -0.4818 & $* *$ & -0.4575 & $* *$ & -0.4594 & $* *$ \\
\hline & $(0.2211)$ & & $(0.2211)$ & & $(0.2211)$ & & $(0.2222)$ & & $(0.2222)$ & \\
\hline \multirow{2}{*}{ Oct 2008 - Sep 2009} & 0.0150 & & 0.0150 & & 0.0151 & & 0.0136 & & 0.0137 & \\
\hline & $(0.0159)$ & & $(0.0159)$ & & (0.0159) & & $(0.0160)$ & & $(0.0160)$ & \\
\hline \multirow{2}{*}{ Oct 2009 - Sep 2010} & 0.0613 & $* * *$ & 0.0613 & $* * *$ & 0.0613 & $* * *$ & 0.0606 & $* * *$ & 0.0606 & $* * *$ \\
\hline & $(0.0167)$ & & $(0.0167)$ & & $(0.0167)$ & & $(0.0167)$ & & $(0.0167)$ & \\
\hline \multirow{2}{*}{$\begin{array}{l}\text { Unemployment - } \\
\text { individual }\end{array}$} & & & -0.1269 & & & & & & -0.1262 & \\
\hline & & & $(0.1178)$ & & & & & & $(0.1177)$ & \\
\hline \multirow{2}{*}{ Real monthly income } & & & & & -0.0009 & & & & -0.0009 & \\
\hline & & & & & $(0.0013)$ & & & & $(0.0013)$ & \\
\hline \multirow{2}{*}{ Real equity } & & & & & & & 0.0029 & & 0.0029 & \\
\hline & & & & & & & $(0.0026)$ & & $(0.0026)$ & \\
\hline
\end{tabular}

Notes: Robust standard errors in parentheses. ${ }^{*} p<0.1,{ }^{* *} p<0.05,{ }^{* *} p<0.01$. Point estimates are computed using linear probability model with individual fixed effects, adjusting for age fixed effects, time trend, seasonality, marital status, number of children in the household, and residency. Estimation models $1,1 b, 4,4 b, 5$, and $5 b$ are indicated by the panel headings. Model 1 is a business-cycle model, model 4 includes business cycles as well as the collapse, and model 5 includes business cycles as well as the crisis period. Models $1 b, 4 b$, and $5 b$ furthermore include the individual-level mediators: individuals' unemployment, real monthly income, and real equity, both added one at a time and in the last column all estimated simultaneously. N=2,661,037. Average number of IHD events per year is 728 for females. Coefficients are interpreted as changes (in percentage points) in the probability of an IHD event. 